\title{
Pre-breakup magmatism on the Vøring Margin: Insight from new sub-basalt imaging and results from Ocean Drilling Program Hole 642E
}

\author{
M.M. Abdelmalak ${ }^{\mathrm{a}, *}$, R. Meyer ${ }^{\mathrm{b}}$, S. Planke ${ }^{\mathrm{a}, \mathrm{c}}$, J.I. Faleide ${ }^{\mathrm{a}}$, L. Gernigon ${ }^{\mathrm{d}}$, J. Frieling ${ }^{\mathrm{e}}$, A. Sluijs ${ }^{\text {e }}$, G.-J. Reichart ${ }^{\mathrm{f}, \mathrm{g}}$, \\ D. Zastrozhnov ${ }^{\mathrm{a}}$, S. Theissen-Krah ${ }^{\mathrm{a}, \mathrm{h}}$, A. Said ${ }^{\mathrm{i}}, \mathrm{R}$ Myklebust $^{\mathrm{j}}$
}

a Centre for Earth Evolution and Dynamics (CEED), University of Oslo, Norway

b GFZ German Research Centre for Geosciences, Section 3.3 Earth Surface Geochemistry, Telegrafenberg, 14473 Potsdam, Germany

c Volcanic Basin Petroleum Research (VBPR), Oslo Science Park, 0349 Oslo, Norway

d Geological Survey of Norway (NGU), Leiv Erikssons vei, 39 Trondheim, Norway

e Marine Palynology and Paleoceanography, Laboratory of Palaeobotany and Palynology, Faculty of Geosciences, Department of Earth Sciences, Utrecht University, Heidelberglaan 2,

3584CS Utrecht, The Netherlands

${ }^{\mathrm{f}}$ Faculty of Geosciences, Department of Earth Sciences, Utrecht University, Heidelberglaan 2, 3584CS Utrecht, The Netherlands

g NIOZ Royal Netherlands Institute for Sea Research, 1790AB Den Burg, Texel, The Netherlands

h GEOMAR-Helmholtz Centre for Ocean Research Kiel, Wischhofstr. 1-3, 24148 Kiel, Germany

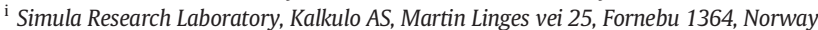

${ }^{\mathrm{j}}$ TGS, Lensmannslia 4, 1386 Asker, Norway

\section{A R T I C L E I N F O}

\section{Article history:}

Received 24 June 2015

Received in revised form 9 January 2016

Accepted 24 February 2016

Available online 9 March 2016

\section{Keywords:}

Pre-breakup

Vøring Margin

ODP Hole 642E

Lower Series Flows

Geochemistry-Biostratigraphy

Early Eocene

Emplacement model

\begin{abstract}
A B S T R A C T
Improvements in sub-basalt imaging combined with petrological and geochemical observations from the Ocean Drilling Program (ODP) Hole 642E core provide new constraints on the initial breakup processes at the Vøring Margin. New and reprocessed high-quality seismic data allow us to identify a new seismic facies unit which we define as the Lower Series Flows. This facies unit is seismically characterized by wavy to continuous subparallel reflections with an internal disrupted and hummocky shape. Drilled lithologies, which we correlate to this facies unit, have been interpreted as subaqueous flows extruding and intruding into wet sediments. Locally, the top boundary of this facies unit is defined as a negative in polarity reflection and referred as the KReflection. This reflection can be correlated with the spatial extent of pyroclastic deposits, emplaced during transitional shallow marine to subaerial volcanic activities during the rift to drift transition. The drilled Lower Series Flows consist of peraluminous, cordierite bearing peperitic basaltic andesitic to dacitic flows interbedded with thick volcano-sedimentary deposits and intruded sills. The peraluminous geochemistry combined with available $\mathrm{C}$ (from calcite which fills vesicles and fractures), $\mathrm{Sr}, \mathrm{Nd}$, and $\mathrm{Pb}$ isotopes data points toward upper crustal rockmantle magma interactions with a significant contribution of organic carbon rich pelagic sedimentary material during crustal anatexis. From biostratigraphic analyses, Apectodinium augustum was found in the Lower Series Flows. This dinoflagellate cyst species is a marker for the Paleocene - Eocene Thermal Maximum (PETM). However, based on very high stable carbon isotope ratios of bulk organic matter we exclude that these strata represent the PETM. This implies that A. augustum was reworked into the early Eocene sediments of this facies unit. Crucially, this unit predates the breakup time of the Vøring Margin.

Finally, a conceptual emplacement model for the Lower Series Flows facies unit is proposed. This model comprises several stages: (1) the emplacement of subaqueous peperitic basaltic andesitic flows intruding and/or extruding wet sediments; (2) a subaerial to shallow marine volcanism and extrusion of dacitic flows; (3) a protobreakup phase with intense shallow marine to subaerial explosive volcanism responsible for pyroclastic flow deposits, which can be correlated with the seismic K-Reflection; and (4) the main breakup stage with intense transitional tholeiitic MORB-type volcanism and large subsidence concomitant with the buildup of the Seaward-Dipping Reflector wedge.
\end{abstract}

(C) 2016 Elsevier B.V. All rights reserved

\footnotetext{
* Corresponding author.

E-mail addresses: m.m.abdelmalak@geo.uio.no, abdelmalak_mansour@yahoo.fr (M.M. Abdelmalak).
}

\section{Introduction}

Continental breakup and initial seafloor spreading in Large Igneous Provinces (LIPs) are accompanied by widespread intrusive and extrusive magmatism and the formation of volcanic passive margins (White and McKenzie, 1989; Coffin and Eldholm, 1994). Extensive 
mantle melting at a volcanic passive margin occurred, before, during, and after plate breakup (e.g., Geoffroy, 2005; Abdelmalak, 2010; Abdelmalak et al., 2012). Magmatic activity is typically expressed within the stretched continental crust by (1) large wedges of seaward-dipping basaltic flows and tuffs extruded at the surface (Hinz, 1981; Eldholm, 1991; Planke et al., 2000; Menzie et al., 2002); (2) massive sill/dyke intrusions within the sedimentary basin (Svensen et al., 2004; Planke et al., 2005); (3) melt emplacements into the upper and mid continental crust by mafic to ultramafic intrusions (Karson and Brooks, 1999; Klausen and Larsen, 2002; Lenoir et al., 2003; Geoffroy et al., 2007; Meyer et al., 2009b); and (4) a high-velocity Lower Crustal Body (LCB) at the base of the crust characterized by high Vp velocity $(\mathrm{Vp}>7.0 \mathrm{~km} / \mathrm{s}$ ) (White et al., 1987; Kelemen and Holbrook, 1995; Holbrook et al., 2001; Mjelde et al., 2009a, 2009b).

The conjugate volcanic rifted margins along the NE Atlantic are the major magmatic component of the North Atlantic Large Igneous Province formed during the final fragmentation of Pangea in the Early Cenozoic (Saunders et al., 1997; Eldholm et al., 2000; Torsvik et al. 2001; Meyer et al., 2007; Hansen et al., 2009; Ganerød et al., 2010). The onset of continental breakup marked a culmination of an approximately 350 Ma period of predominantly extensional deformation and intermediate cooling events subsequent to the Caledonian orogeny (Ziegler, 1988; Doré et al., 1999; Skogseid et al., 2000; Tsikalas et al., 2008). As part of this volcanic rift system, the Vøring Margin experienced a prolonged history of intermittent extension and basin formation, prior to the early Cenozoic continental breakup (Eldholm and Grue, 1994; Brekke, 2000; Gernigon et al., 2004; Lundin and Doré, 2005; Faleide et al., 2008, 2010; Tsikalas et al., 2012). The final continental breakup occurred near the Paleocene-Eocene transition ( $56 \mathrm{Ma}$ according to Gradstein et al., 2012 timescale) just after a 3-6 Ma period of massive magmatic activity (Eldholm and Grue, 1994; Eldholm et al., 2000). Continental breakup resulted in voluminous igneous activity generating both extrusives and intrusives into the adjacent sedimentary basin and pre-existing (continental) crust (Hinz, 1981; Mutter et al., 1982; White and McKenzie, 1989; Eldholm and Grue, 1994; Mjelde et al., 2007; Breivik et al., 2014).

The transition from a sedimentary amagmatic rift toward the formation of the volcanically dominated rift is highly speculative in volcanic passive margins. The thick overlying accumulation of extrusive and intrusive rocks always represents a challenge for seismic imaging methods, despite the major improvements in geophysics during the last decades to understand the rift to drift evolution. This unsatisfying situation led to major uncertainties of sub-basalt rift architecture and dynamics interpretations. However, detailed petrogenic studies of the breakup-related igneous rocks already provided important insights into the processes and the geodynamic history associated with continental breakup (Meyer et al., 2007, 2009a, 2009b).

In this paper, we investigate in detail the pre-breakup magmatism in the North Atlantic area by addressing the example of the Vøring volcanic margin. For this matter, we used new and reprocessed seismic data, in combination with updated stratigraphic and petrological data from the Ocean Drilling Program (ODP) Hole 642E to constrain the nature, composition, and emplacement mechanisms of the igneous rock successions erupted during the pre-breakup stages of the Vøring Margin. We finally obtained new palynological and stable carbon isotope data on organic material to better constrain the breakup ages of the Vøring Margin.

\section{Regional setting: the Vøring rifted margin}

The Vøring rifted margin is bounded by the Jan. Mayen Fracture Zone to the southwest and the Bivrost Lineament to the northeast (Blystad et al., 1995). The $\sim 500 \mathrm{~km}$ wide Vøring Margin comprises the Trøndelag Platform, the Vøring Basin, and the Vøring Marginal High (VMH) (Fig. 1). The Vøring Margin was particularly affected by a significant late Jurassic to early Cretaceous crustal thinning phase and later subsidence leading to a very thick Cretaceous depocenter (Blystad et al., 1995; Skogseid et al., 2000; Scheck-Wenderoth et al., 2007). This significant sedimentary Cretaceous thickness ( $10 \mathrm{~km}$ deep) mostly concealed the geometry of the deeper and older syn-rift sequences in the Vøring Basin (Faleide et al., 2008). The thinned crust of the Vøring Margin was, again, the locus of a new phase of extensional deformation in the latest Cretaceous-Paleocene. This extensional phase is particularly well documented in the outer Vøring Basin (Eldholm et al., 2002; Gernigon et al., 2003; Ren et al., 2003). These different extensional phases are responsible for the formation of large-scale rift blocks or structural highs (early Cretaceous ridges and highs: Rån Ridge, Utgard High; late Cretaceous-early Paleocene ridges and highs: North/South Gjallar Ridge, Nyk High, Mimir High, Ygg High, Grimm High, and Skoll High) (Fig. 3A). Many of these rift blocks are poorly imaged on seismic data in the deeper part of the basin and/or when these blocks are located beneath intrusive and extrusive igneous rocks. Still today, after decades of extensive research within this economically and academically highly important area, the present knowledge on the pre-Cretaceous geology within the outer Vøring Basin remains highly speculative. In the outer Vøring Basin, the deepest borehole calibration only reaches Early Cretaceous formation (e.g., Dalsnuten well 6603/5-1S located in the South Gjallar Ridge, see Fig. 3A). Older sedimentary formations remain unconstrained. Based on seismic data, earlier extensional phases and pre-Cretaceous (Permian to Jurassic?) sedimentary strata are however probable and locally interpreted in the southwestern Vøring Basin (Gernigon et al., 2003).

The magmatic-tectonic processes that lead to the final breakup at the Vøring Margin had been restricted to a 100-150 km wide region of the outer Vøring Basin and Vøring Marginal High presently situated to the east of the first defined oceanic magnetic chrons. At the Vøring Margin, significant volumes of flood basalts erupted in submarine to subaerial settings during the onset of breakup (e.g., Berndt et al., 2001). These peculiar volcanic successions display a large variety of seismic facies that are indicative of the style of volcanic emplacement, depositional environment, and subsequent mass transport (Planke and Alvestad, 1999; Planke et al., 1999, 2000; Brendt et al., 2001; Jerram et al., 2009; Wright et al., 2012; Abdelmalak et al., submitted for publication). The volcanic sequences emplaced during the onset of the breakup, partially masked seismically the Late Cretaceous-Eocene and older sedimentary strata and continental structures inferred in the outermost part of the Vøring Margin. Outside and below the lava flow domains, seismic observations report voluminous magmatic complexes of dominantly sub-horizontal sheets ( sills) intruding pre-breakup sedimentary rocks. The sill intrusions cover an area of more than $85000 \mathrm{~km}^{2}$ offshore mid-Norway (Planke et al., 2005).

Insights about the onset of breakup in the outer part of the Vøring Margin have been provided from the scientific drilling campaign at the Vøring Marginal High. ODP Leg 104 Hole 642E has been highly successful while recovering a spectacular $900 \mathrm{~m}$ thick igneous rock succession of MORB-type basalts overlying glassy crustal anatectic peralouminous flows emplaced during the Vøring Margin formation (e.g., Viereck et al., 1989). The recovered igneous succession from Hole $642 \mathrm{E}$ covers the rift to drift magmatic evolution and is considered to provide intrinsic petrological constraints on the initial breakup history and the subsequent volcanic margin evolution (e.g., Meyer et al., 2009a).

\section{Data and methods}

\subsection{Data}

This work is essentially based on the interpretation of more than 500 regional 2D seismic lines with a total length of more than $80000 \mathrm{~km}$ (with a line spacing ranging between 0.2 and $2 \mathrm{~km}$ ) covering the entire area of the Vøring Margin. This exceptional data set includes recently 


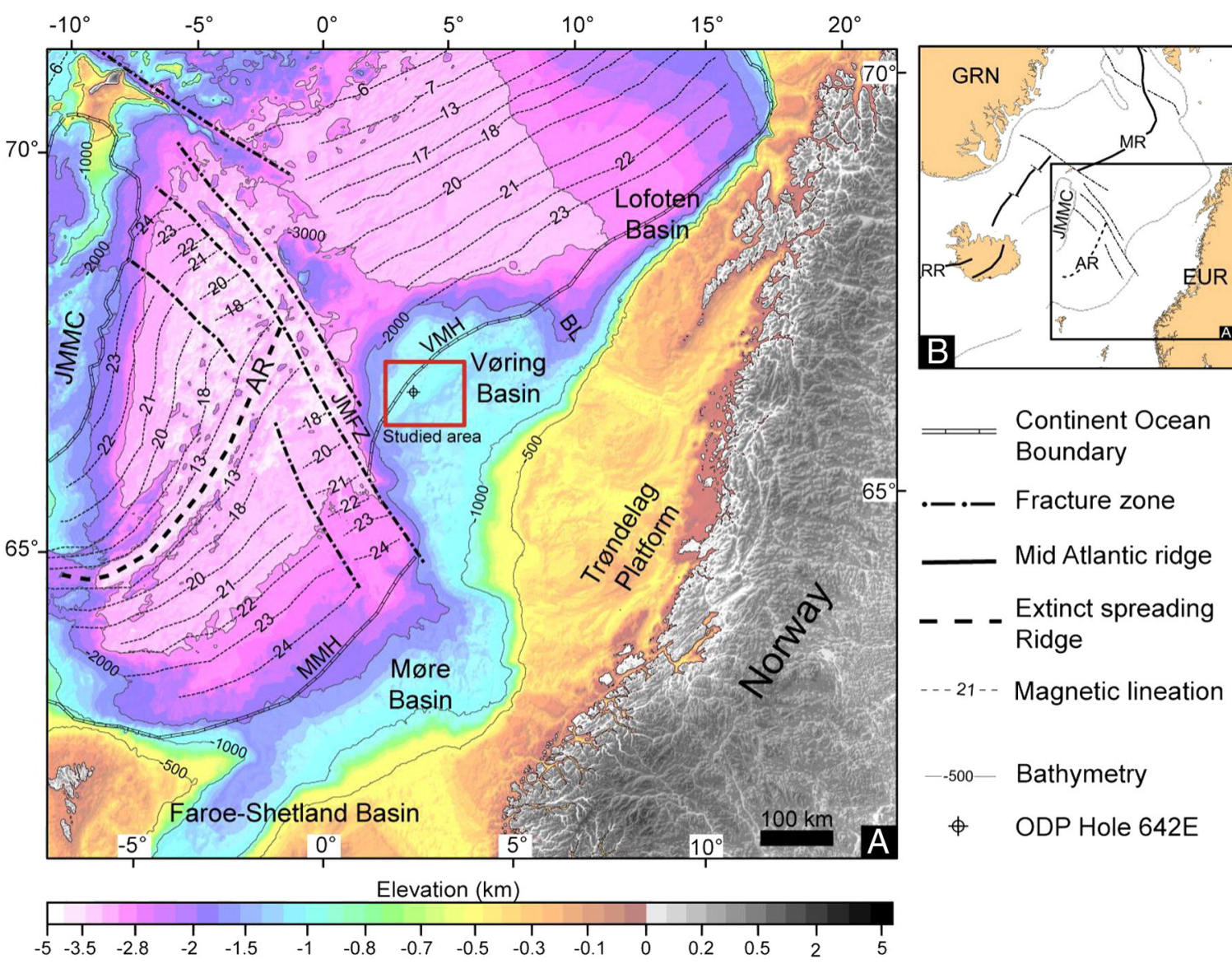

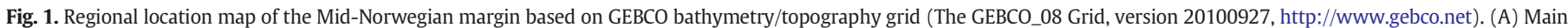

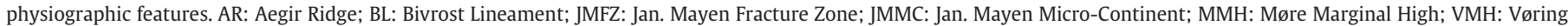
Marginal High. (B) Location of the regional map in the North Atlantic Area. EUR: Eurasia; GRN: Greenland; MR: Mohn's Ridge; RR: Reykjanes Ridge.

recorded, in addition to reprocessed high-quality seismic reflection data, which provide an improved imaging of the deeper parts of the margin. The line coverage of the data is dense enough to correlate laterally the different facies units along the mid-Norwegian Margin. Selections of the used seismic lines inside our studied area are presented in Fig. 3A. In this study, we use the concept of seismic volcanostratigraphy for the interpretation of large volcanic constructions (e.g., Planke et al., 2000; Berndt et al., 2001). To support the seismic interpretation, we use public-domain bathymetry (e.g., GEBCO, the GEBCO_08 Grid, version 20,100,927, "http://www.gebco.net“) satellite gravity (Sandwell and Smith, 2009), released magnetic data (EMAG2) (Maus et al., 2009), and local aeromagnetic data from the Geological Survey of Norway and TGS.

The original core stratigraphy of ODP Hole 642E (e.g., Eldholm et al., 1987) with small modifications presented by Meyer et al. (2009a) has been correlated with our new seismic profiles. The ODP Hole 642E is located near the apex of the seaward-dipping reflector wedge (SDR) and situated at $\sim 25 \mathrm{~km}$ west of the Vøring Escarpment (Fig. 3). In addition to seismic profile and petrological data, we also analyzed palynology and stable carbon isotope ratios from bulk organic matter for 16 samples across the 1154.02-1211.58 meters below sea floor (mbsf) interval in Hole 642E.

\subsection{Methods}

\subsubsection{Palynology}

For each sample, 5-15 g was processed for palynology, using standard procedures (Sluijs et al., 2011), including treatment with $\mathrm{HCl}$ and HF for carbonate and silica removal, respectively. Samples were sieved with water over a 250 and $15 \mu \mathrm{m}$ mesh sieve to remove large and small particles, respectively. Residues were concentrated in glycerine water and mounted on microscope slides using glycerine jelly and analyzed at $400 \times$ magnification.

\subsubsection{Stable isotope analysis of total organic carbon}

We selected 16 samples that contained abundant palynomorphs and measured stable carbon isotopes from total organic carbon $\left(\delta^{13} \mathrm{C}_{\mathrm{TOC}}\right)$. Samples were decalcified using two $1 \mathrm{M} \mathrm{HCl}$ steps. Stable carbon isotope ratios were determined on 15-30 $\mu$ g of decalcified sediment using an isotope ratio mass spectrometer (IRMS, Finnigan Mat Delta Plus). The influence of variable marine contribution to the organic matter can be assessed using the equation of Sluijs and Dickens (2012), which assumes a constant offset of $4.4 \%$ between marine and terrestrial organic matter. Absolute reproducibility, based on international and in-house standards is better than $0.05 \%$.

\section{Core properties of Hole $642 \mathrm{E}$}

Many contributions have been published about the ODP Hole 642E after the initial proceedings of this drilling campaign (Eldholm et al., 1987). These studies mainly focused on the lithostratigraphy (Eldholm et al., 1989a, 1989b), biostratigraphy (Boulter and Manum, 1989), the seismic response of the flood basalts (Planke, 1994; Planke and Eldholm, 1994), and the petrogenesis of the volcanic units recovered at Hole 642E (Parson et al., 1989; Viereck et al., 1989; Meyer et al., 2009a).

The recovered ODP Hole 642E lithology consists of an ca. 320 m thick sequence of marine sedimentary rocks covering the extrusive complexes, which have been divided into an Upper Series and a Lower Series 


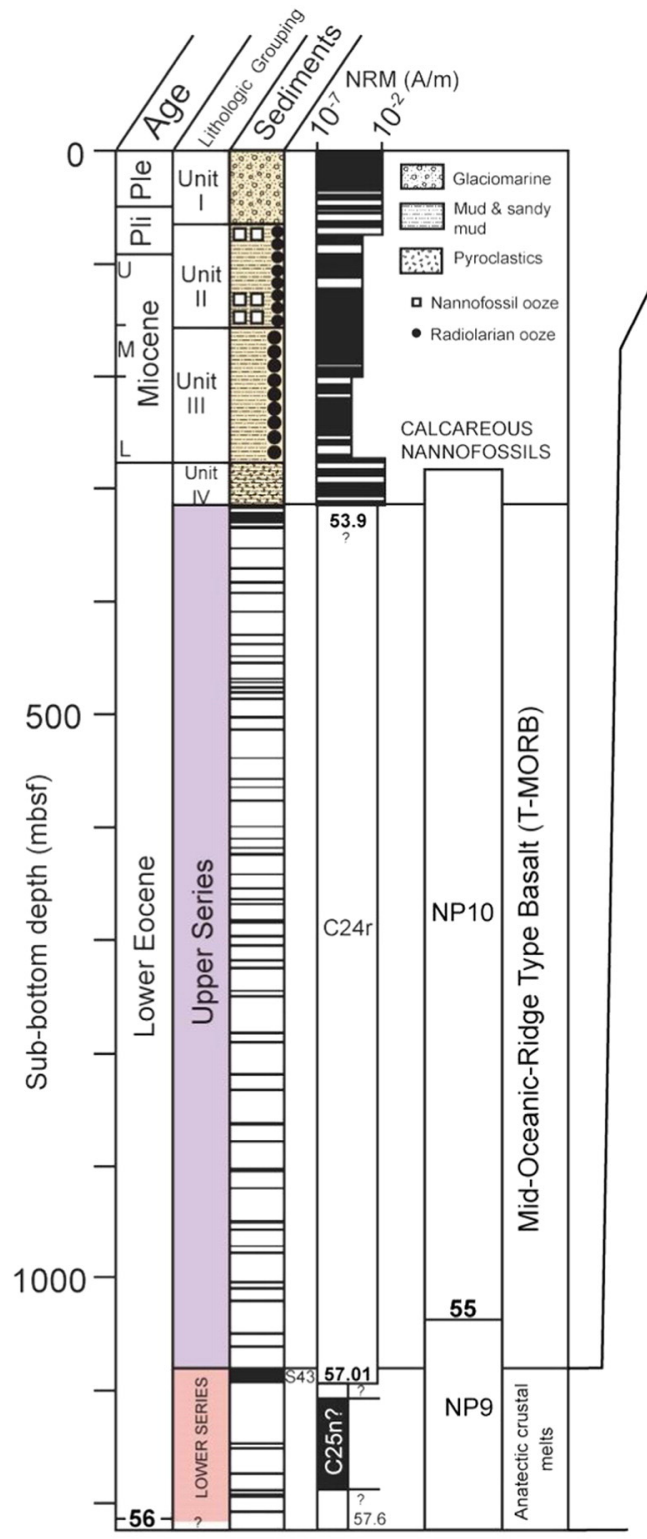

A ODP Hole 642E

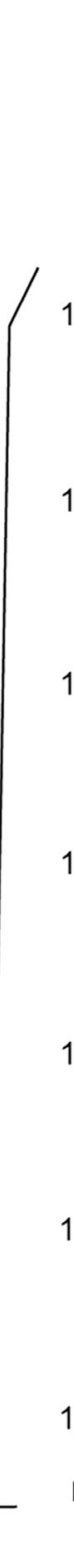

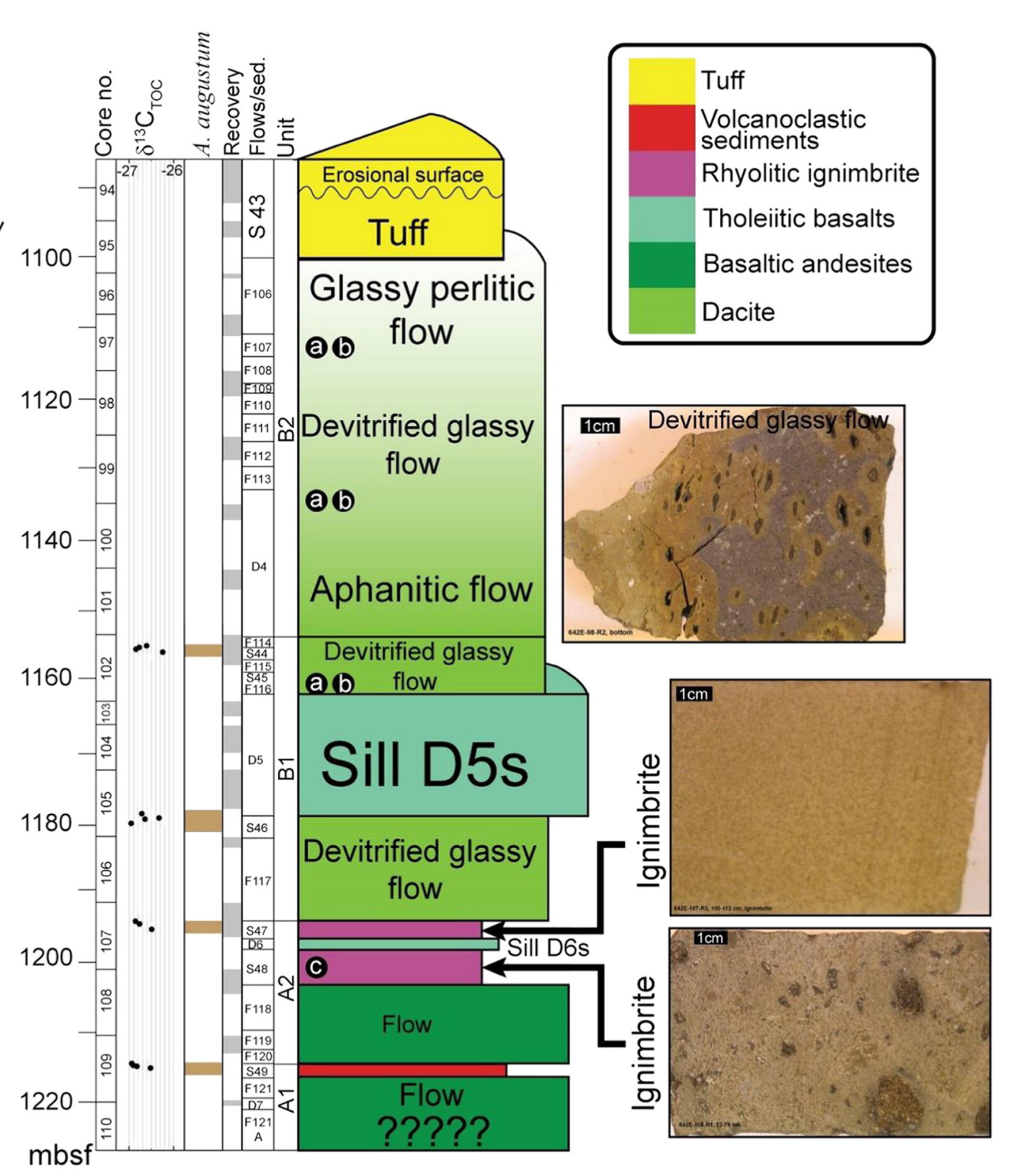

B The Lower Series stratigraphy

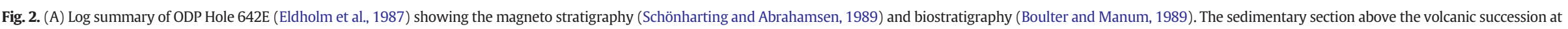

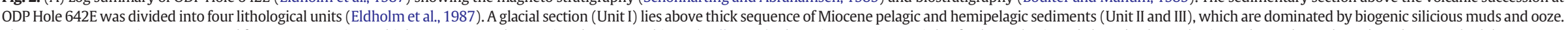

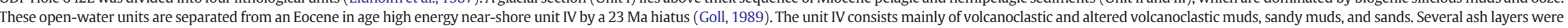

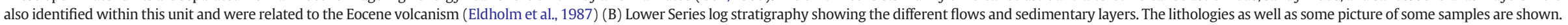

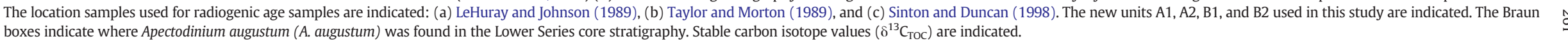


(Eldholm et al., 1989b) (Fig. 2). These two volcanic series show distinct textural, structural, physical, mineralogical, and chemical characteristics and also different composition of the interlayered volcanoclastic sediments (Eldholm, 1991).

The Upper Series (US) is about 770 m thick and consists mainly of basaltic lava flows and interbedded sediments with a core recovery of $42.6 \%$. The Upper Series comprises ca. 121 individual tholeiitic lava flows, three intrusions (interpreted as crosscutting dykes), and 52 volcanoclastic sedimentary layers. These sediment deposits represent around 3-7\% of the stratigraphy within the Upper Series lithology (Planke and Eldholm, 1994). These rock successions correspond to the seismically characterized Seaward-Dipping Reflector (SDR) and is of transitional tholeiitic mid oceanic ridge basalt (T-MORB) composition (Viereck et al., 1989; Meyer et al., 2009a).

The Upper Series is overlying an approximately $130 \mathrm{~m}$ drilled Lower Series (LS) with a core recovery of 32.4\% (Eldholm et al., 1987, 1989a). Drilling activity stopped within this spectacular glassy lava flow sequence. Between 1100 and 1229.4 mbsf (meters below sea floor), 18 extrusive flow units, 2 intrusions, and 7 individual sedimentary units (representing $\sim 20 \%$ of the recorded core stratigraphy of the Lower Series) were described in the early reports (Eldholm et al., 1987, 1989a; Eldholm, 1991).

The Lower Series comprises rhyolitic ignimbrites, tholeiitic basaltic intrusions, basaltic andesite, and dacitic lava flows (Fig. 2). Below 1086.8 mbsf, an approximately $13 \mathrm{~m}$ thick volcano-sedimentary/ tuffaceous unit (S43) can be interpreted as the transition from the Upper Series to the Lower Series. The Lower Series is believed to result from interaction of mantle melts with continental crustal material and/or significant crustal melting by magmatic underplating (Parson et al., 1989; Meyer et al., 2009a).

\section{Age of volcanism}

The entire Upper Series drilled at Hole 642E shows a reversed magnetic polarity acquired during rapid extrusion correlated within magnetic polarity Chron C24r ( $\sim 57$ to $\sim 54$ Ma following Vandenberghe et al. (2012) and Gradstein et al. (2012)) (Fig. 2A) (Eldholm et al., 1989a; Schönharting and Abrahamsen, 1989; Eldholm, 1991; Sinton and Duncan, 1998). Ocean-ward, the main SDR wedge shows a positive magnetic signature possibly correlated with Chrons C24n3n and C24n1n (i.e., between 54-53 Ma). These magnetic signatures are now well documented by modern aeromagnetic surveys in the Lofoten and Norway basins but less clearly observed in the outer part of the Vøring Marginal High (Olesen et al., 2007; Gernigon et al., 2009, 2015). The magnetic polarity distribution of the Lower Series is complex due to widespread remagnetization effects (Eldholm et al., 1989a; Schönharting and Abrahamsen, 1989). A normal polarity zone was measured between 1113 and 1194 mbsf and tentatively correlated with Chron C25n (57.01 to 57.6 Ma according to the chronostratigraphic time scale of Gradstein et al. (2012)) (Schönharting and Abrahamsen, 1989; Eldholm, 1991).

Radiometric age determinations have been accomplished on different samples from the Lower Series to provide crystallization ages (Fig. 2B). LeHuray and Johnson (1989) provide Rb-Sr ages of $54.5 \pm$ 0.2 and $57.8 \pm 1.0 \mathrm{Ma}$, for the top of the Upper Series and the Lower Series, respectively. While Taylor and Morton (1989) measured for the Lower Series samples Rb-Sr age of $63 \pm 19$ Ma, Sinton et al. (1998) reported ${ }^{40} \mathrm{Ar}-{ }^{39} \mathrm{Ar}$ incremental heating ages of the Lower Series rocks. However, these authors noticed that the used samples were generally altered, making them no optimal samples for radiometric dating. Their presented age spectra for the Lower Series were "somewhat disturbed" but suggesting a crystallization age of 55-56 Ma (Sinton et al., 1998).

Palynological studies of the intrabedded sedimentary layers have identified the Apectodinium hyperacanthum dinoflagellate cyst zone of Costa and Downie (1976) in the volcanic series from Hole 642E, which was considered equivalent to nannoplankton zones NP9 and the NP10
(Harland, 1979) (Fig. 2A and Boulter and Manum, 1989). The most recent time scale dates these zones between $\sim 57$ and $54 \mathrm{Ma}$ (Vandenberghe et al., 2012). The Upper Series has been linked to the uppermost nannoplankton zone NP9 and the NP10 zone (Boulter and Manum, 1989), (indicating an age ranging between $\sim 55$ and $54 \mathrm{Ma}$ according to (Gradstein et al. (2012) time-scale). The Lower Series has been linked to the nannoplankton zone NP9 and the lowermost NP10 zone (Boulter and Manum, 1989), and postulating so an age ranging between 57.3 and $55 \mathrm{Ma}$.

Crucially, Boulter and Manum (1989) also recorded the species Apectodinium augustum, a species that is now considered to be diagnostic of the Paleocene-Eocene Thermal Maximum (PETM) (Schmitz et al., 2004; Sluijs et al., 2006). The PETM was a 170 kyr long phase of global warming (Röhl et al., 2007; Murphy et al., 2010), currently dated at 56 Ma ago (e.g., Charles et al., 2011; Westerhold et al., 2012). Our new palynological investigations confirm the presence of $A$. augustum across the entire analysed interval (1154.02-1211.58 mbsf, Fig. 2B).

The PETM is associated with a $2.5-8 \%$ o negative Carbon Isotope Excursion (CIE) of the global exogenic carbon pool (McInerney and Wing, 2011). This negative carbon isotope excursion can be found in all carbon bearing substrates, deposited during the PETM. Based on the presence of A. augustum we hence expect organic matter to record extremely low $\delta^{13} \mathrm{C}$ values reflecting the low carbon isotope signature of the ocean and atmosphere during the PETM. In the North Sea, North Atlantic and Arctic Ocean, the PETM bulk organic $\delta^{13} \mathrm{C}$ values are maximally $-28 \%$ o but more typically between $-30 \%$ and $-32 \%$ 。 (Sluijs and Dickens, 2012). However, we record bulk organic $\delta^{13} \mathrm{C}$ values around $-26.7 \%$ o $( \pm 0.2 \%$ ) (Fig. $2 B$ ). Such values are typical for early Eocene marine sedimentary sequences (Hayes et al., 1999) but too high to reflect the PETM (Sluijs and Dickens, 2012). Changes in the relative abundance of terrestrial and marine organic matter may alter the carbon isotopic signature (Sluijs et al., 2012). However, palynological residues do not support extreme abundances of terrigenous organic matter that may skew bulk organic $\delta^{13} \mathrm{C}$ values to the recorded high values. The sedimentary units of ODP Hole 642E were thus not deposited during the PETM and this implies that the specimens of A. augustum are reworked.

We did not record many other dinocyst taxa we may use to refine the age of the sediments. Notably, however, we did not record any specimens of the genus Wetzeliella, which originates in the earliest Eocene, about one million years after the PETM (e.g., Williams et al., 2004). We therefore tentatively suggest that the sediments were deposited within the first million years of the Eocene.

\section{Volcanic facies units mapping}

Recent advances in seismic data processing along the Vøring Margin have significantly improved imaging of geometries within the volcanic deposits as well as in the sediments below the basalts and allow better constraints on the breakup-related igneous rocks. The regional extent of the extrusive breakup complex was reinterpreted on seismic reflection data primarily on the basis of its top reflection. This top basalt reflection is easily identifiable due to the high impedance contrast between the post-breakup sediments and the volcanics. The top of the basaltic sequences is an unconformity/conformity between the post-breakup sediments and the underlying basaltic rocks and represents the continent-ward continuation of the top oceanic basement reflection further west. It is often smooth but may locally be irregular, faulted, and could show evidence of pseudo-escarpments (Planke et al., 2000; Berndt et al., 2001; Abdelmalak et al., submitted for publication).

The basal sequence boundary is generally difficult to identify. This is mainly due to imaging problems related to the seismic properties of the overlying basaltic constructions. The high impedance contrasts at the top/within the lava pile give rise to a scattering of the seismic energy. In addition, the lower boundary of the volcanic extrusive complexes is often poorly defined. Furthermore, the base of the basalt can consist of a transitional and composite zone of sequentially extrusive volcanics rocks mixed with subsequently intruded sills and volcanoclastic 

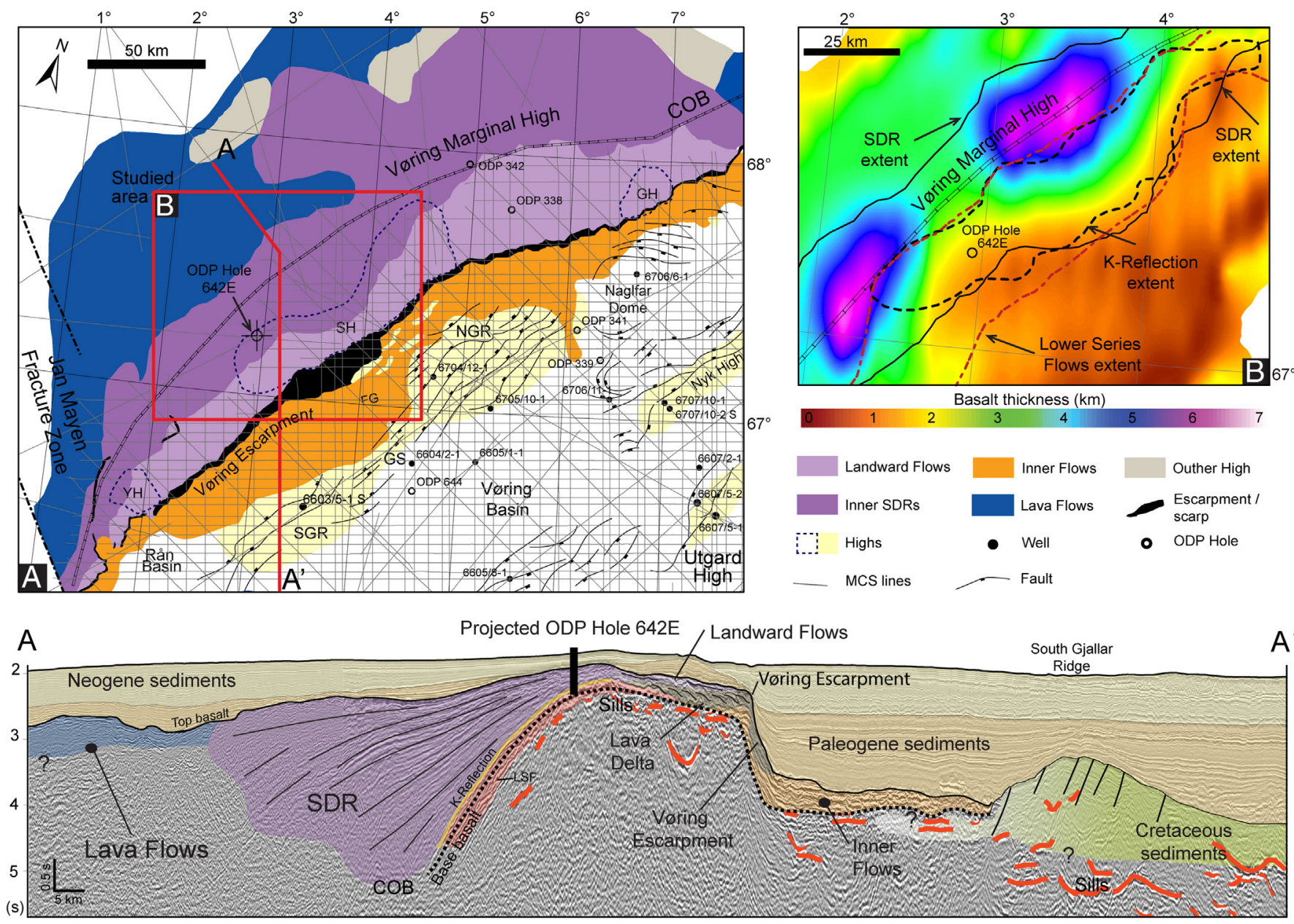

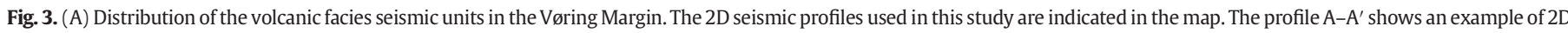

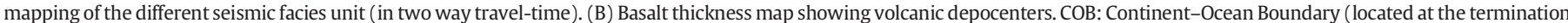

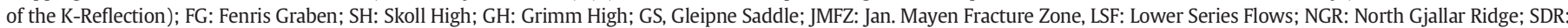
Seaward-Dipping Reflector; SGR: South Gjallar Ridge; YH: Ygg High.

Table 1

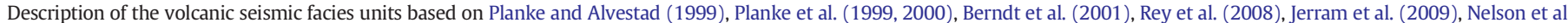
(2009).

\begin{tabular}{|c|c|c|c|c|c|}
\hline \multirow{2}{*}{$\begin{array}{l}\text { Seismic } \\
\text { facies unit }\end{array}$} & \multicolumn{3}{|c|}{ Reflections characteristics } & \multirow{2}{*}{ Volcanic facies } & \multirow{2}{*}{ Depositional environment } \\
\hline & Shape & Boundaries & Internal & & \\
\hline Inner Flows & Sheet & $\begin{array}{l}\text { Top: high amplitude, disrupted, } \\
\text { rough being onlapped or concordant. } \\
\text { Base: negative polarity often } \\
\text { obscured }\end{array}$ & $\begin{array}{l}\text { Chaotic sheet-like body of very } \\
\text { disrupted or hummocky } \\
\text { reflections }\end{array}$ & $\begin{array}{l}\text { Massive and fragmented flows, } \\
\text { volcanoclastics and hyaloclastics }\end{array}$ & $\begin{array}{l}\text { hallow marine deposited in } \\
\text { broad basin }\end{array}$ \\
\hline Lava Delta & Bank & $\begin{array}{l}\text { Top: high amplitude or reflection } \\
\text { truncation. Base Reflection truncation } \\
\text { or termination }\end{array}$ & $\begin{array}{l}\text { Progradational reflection } \\
\text { configuration }\end{array}$ & $\begin{array}{l}\text { Massive and fragmented basalts } \\
\text { and volcanoclastics }\end{array}$ & Coastal \\
\hline Landward Flows & Sheet & $\begin{array}{l}\text { Top: high amplitude, smooth being } \\
\text { onlapped or concordant. Base: law } \\
\text { amplitude, disrupted }\end{array}$ & $\begin{array}{l}\text { Parallel to subparallel. } \\
\text { High-amplitude disrupted }\end{array}$ & Flood basalts & $\begin{array}{l}\text { Subaerial or shallow marine } \\
\text { flood basalts deposited on a } \\
\text { plain or in broad basin }\end{array}$ \\
\hline Inner SDR & Wedge & $\begin{array}{l}\text { Top: intermediate to high amplitude, } \\
\text { smooth with pseudoescarpment. } \\
\text { Base: seldom defined }\end{array}$ & $\begin{array}{l}\text { Divergent arcuate or sometimes a } \\
\text { divergent-planar pattern }\end{array}$ & Flood basalts & $\begin{array}{l}\text { Subaerial flood basalts deposited } \\
\text { in subsiding structure }\end{array}$ \\
\hline Outer High & Mound & $\begin{array}{l}\text { Top: high amplitude, disrupted and } \\
\text { rough. Base: not visible }\end{array}$ & Chaotic & $\begin{array}{l}\text { Hyaloclastic flows and } \\
\text { volcanoclastics }\end{array}$ & Shallow marine environment \\
\hline Outer SDR & Wedge & $\begin{array}{l}\text { Top: Intermediate to high amplitude, } \\
\text { smooth with pseudoescarpment. } \\
\text { Base: seldom defined }\end{array}$ & $\begin{array}{l}\text { Divergent arcuate internal } \\
\text { reflectors, lower amplitude than } \\
\text { the Inner SDR }\end{array}$ & $\begin{array}{l}\text { Flood basalts mixed with pillow } \\
\text { basalts sediments and sills }\end{array}$ & $\begin{array}{l}\text { deep marine depositional } \\
\text { environment }\end{array}$ \\
\hline Lava Flows & Sheet & $\begin{array}{l}\text { Top: high amplitude with } \\
\text { pseudoescarpment. Base: not visible }\end{array}$ & Chaotic & Flood basalts & $\begin{array}{l}\text { Subaerial to shallow submarine } \\
\text { depositional environment }\end{array}$ \\
\hline
\end{tabular}




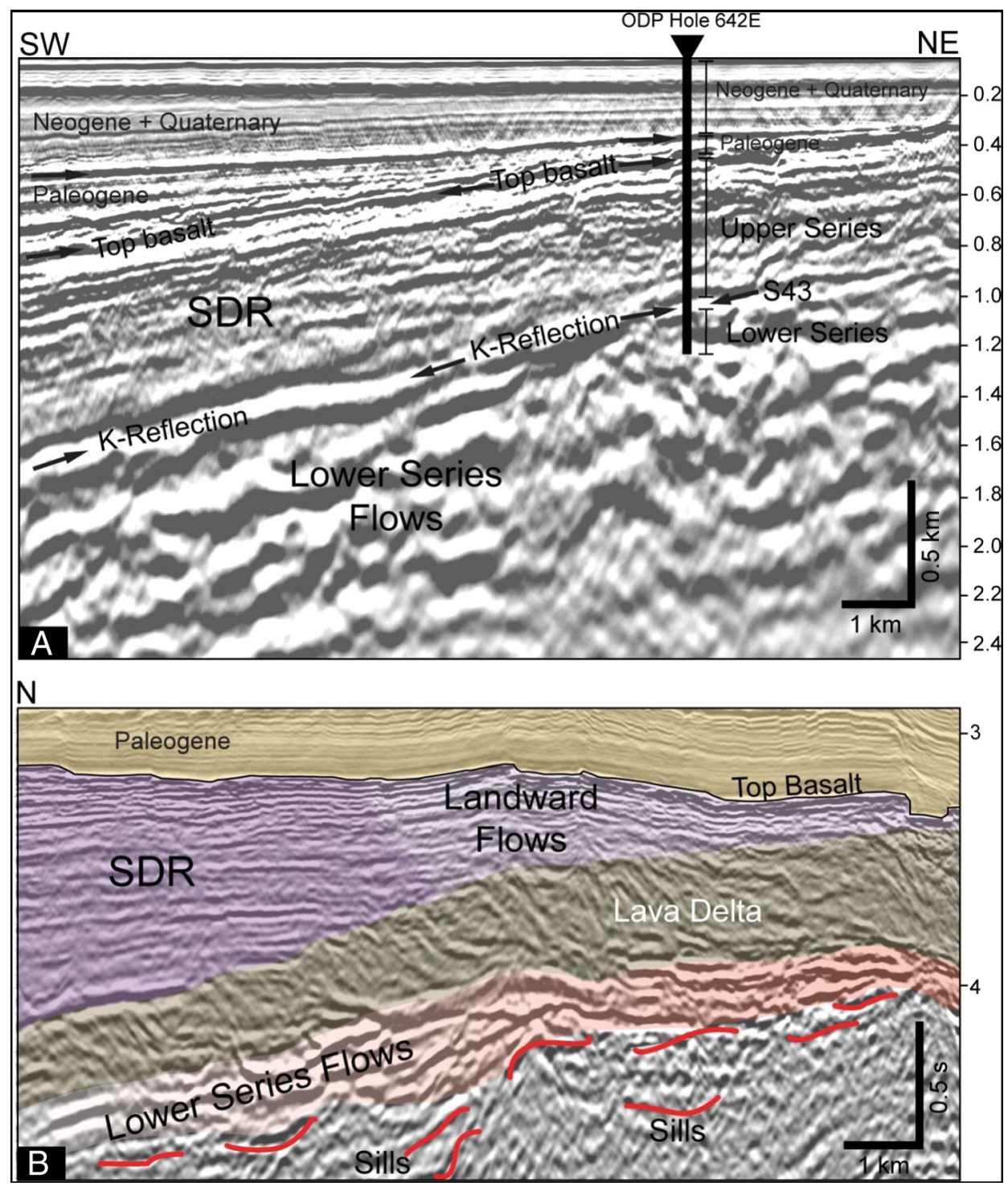

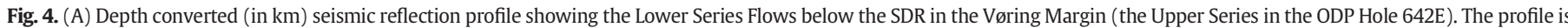

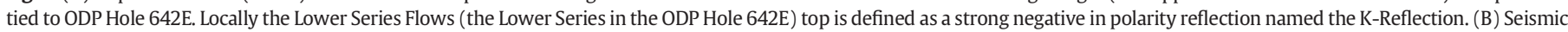

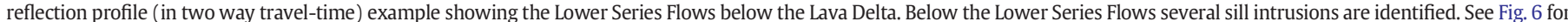
seismic profile location.

ments. Locally basaltic sequences lie over the intruded sedimentary basin. In such case, we assumed that the base of the basalts should be above the sill intrusions identified on seismic profiles (Fig. 3).

Improved multichannel seismic (MCS) data have allowed the definition and characterization of a more complete seismic "volcanostratigraphy" based on reflection pattern, their shape and boundary reflections (Planke et al., 2000; Berndt et al., 2001). As a result, several volcanic seismic facies units have been identified: (1) Landward Flows, (2) Lava Delta, (3) Inner Flows, (4) Inner Seaward-Dipping Reflectors (Inner SDR), (5) Outer High, and (6) Outer SDR (Fig. 3). Such facies successions represent a typical volcanic rifted margin sequence and describe the volcano-tectonic history during the breakup. Some seismically undifferentiated Lava Flows located between the inner SDR and the normal oceanic crust are also mapped (see Table 1). The profile A$A^{\prime}$ in Fig. 3 illustrates the main volcanostratigraphic sequences of the Vøring volcanic margin tied to Hole 642E.

By using the top and the base basalt defined on seismic profiles, we established a basalt thickness map while considering an average velocity of $4 \mathrm{~km} \mathrm{~s}^{-1}$ in basalt, (e.g., Planke, 1994). By assuming such a constant velocity value, the basalt thickness should increase from several hundred meters in the Inner Flows to more than $6 \mathrm{~km}$ in the SDR domain. In our study area (Fig. 3B), mapping results illustrate separate depocenters in the SDR domain. These features could be explained by local variations in the accommodation space possibly controlled by tectonism during the SDRS growth.

\section{The Lower Series Flows facies unit (Lower Series in ODP Hole 642E)}

From the high-quality seismic reflection data (examples of used representative seismic profiles are shown in Fig. 3), a new seismic facies unit is defined in the volcanostratigraphic sequence and called hereafter the Lower Series Flows. This facies unit is identified below the SDR wedges, the Landward Flows (Figs. 4A and 5) and occasionally below the Lava Delta facies units (Fig. 4B). Tied to the ODP Hole 642E, this facies unit corresponds to the Lower Series (Fig. 4A). Locally, the top boundary of the Lower Series Flows is defined as a strong and continuously negative in polarity reflection (Fig. 4A), called the K-Reflection. In the seismic reflection profiles the Lower Series Flows facies unit is characterized by thick strong wavy to continuous high-amplitude 

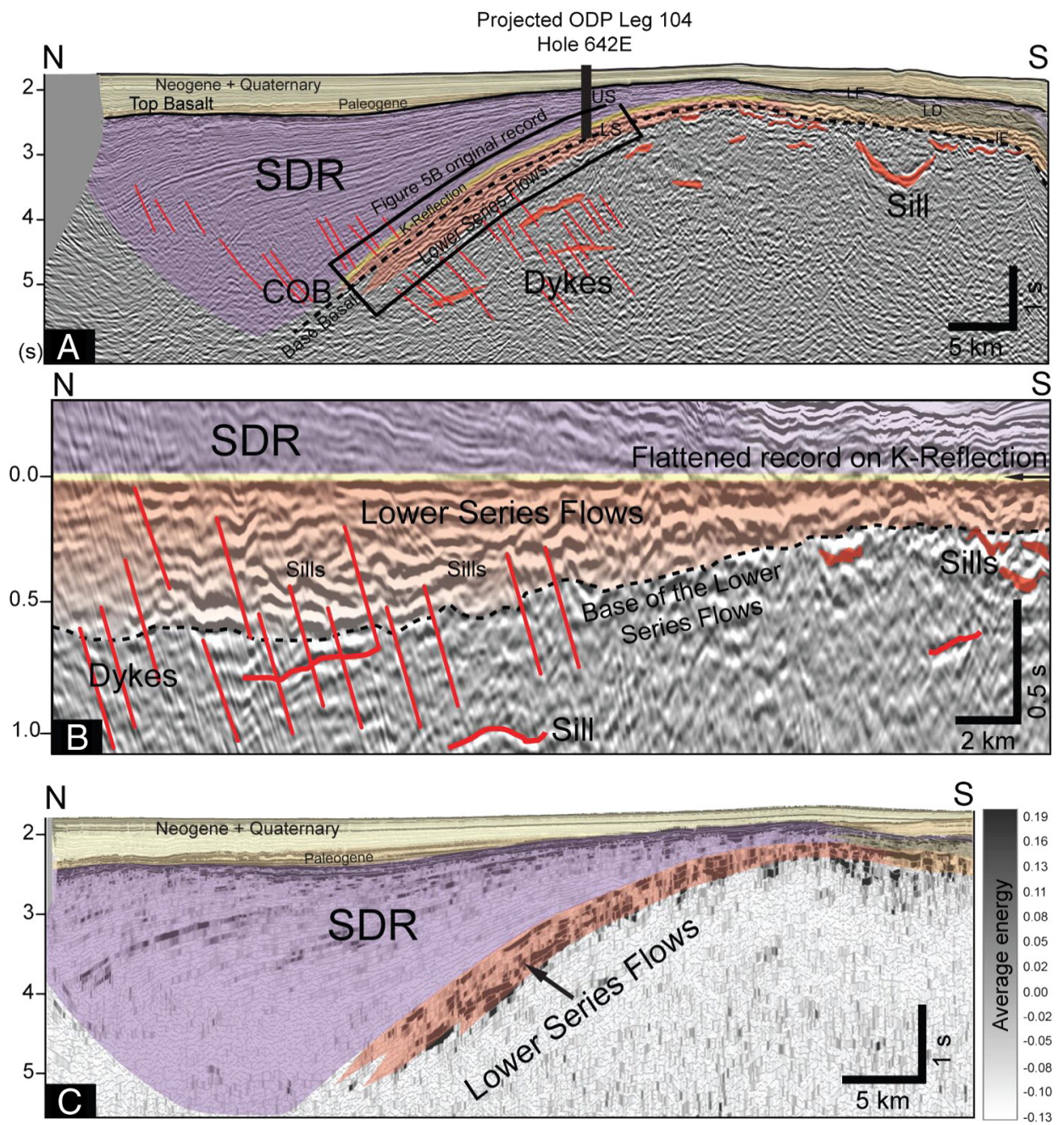

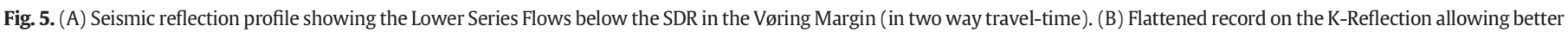

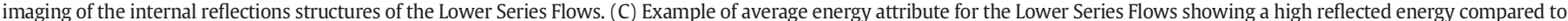
the Inner SDR and the underlying structures. IF: Inner Flows; LF: Landward Flows; LD: Lava Delta; LS: Lower Series; US: Upper Series. See Fig. 6 for seismic profile location.
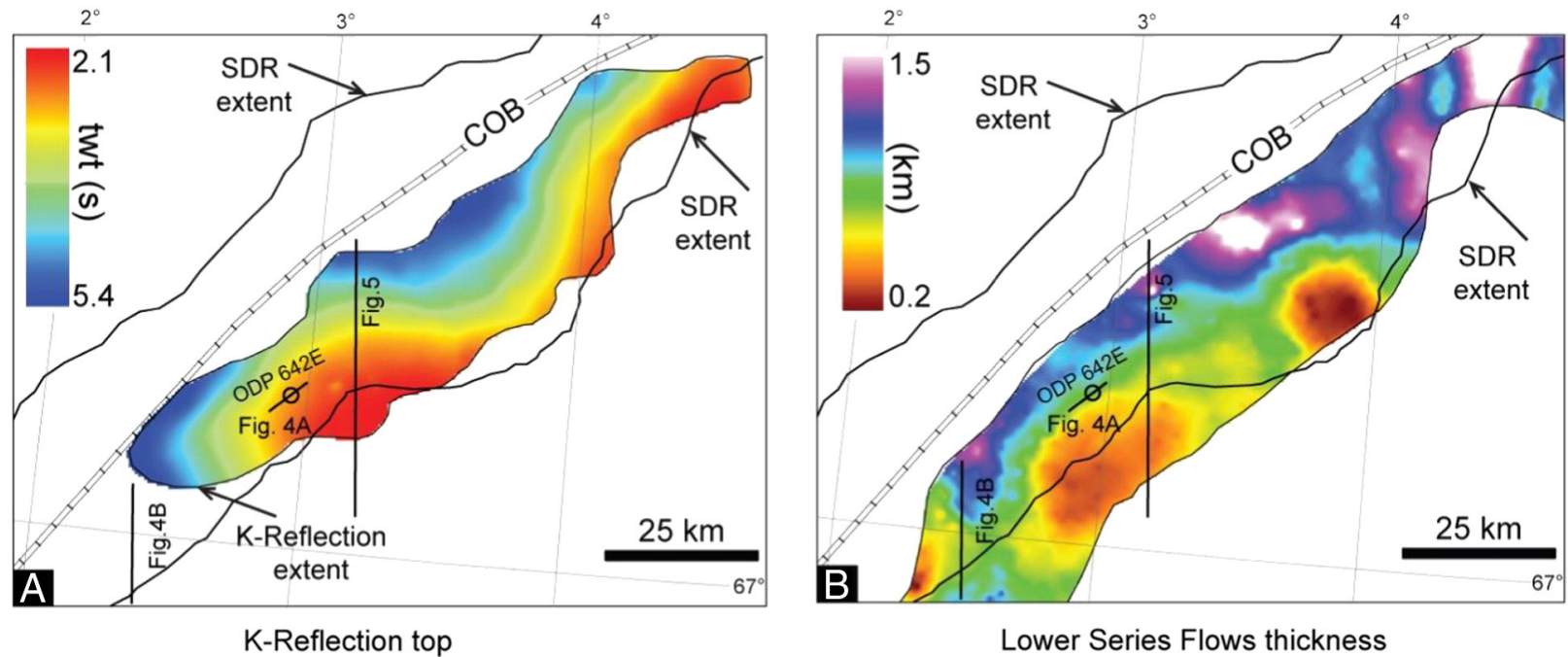

Lower Series Flows thickness

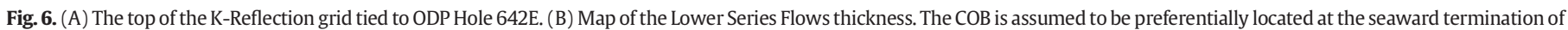
$\mathrm{K}$-Reflection. The grid is calculated using an average velocity of $4 \mathrm{~km} \mathrm{~s}^{-1}$ 
Table 2

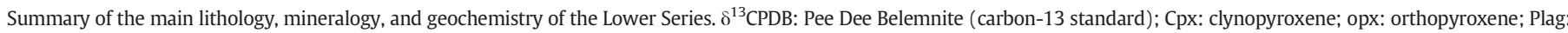
plagioclase. Results from [a]: Meyer et al. (2009a); [b] Love et al. (1989).

\begin{tabular}{|c|c|c|c|c|c|}
\hline $\begin{array}{l}\text { Lithological } \\
\text { units }\end{array}$ & Mineralogy/glass content & $\begin{array}{l}\text { Major elements } \\
\text { (wt.\%) [a] }\end{array}$ & Trace elements [a] & $\begin{array}{l}\delta^{13} \mathrm{C}_{\mathrm{PDB}} \\
(\%)[\mathrm{b}]\end{array}$ & Comments/interpretation \\
\hline Flow unit A1 & $\begin{array}{l}\text { Porphyric texture with a glassy } \\
\text { (ca. } 25 \text { Vol.\%) matrix and plag, } \\
\text { opx, and cpx phenocrysts }\end{array}$ & $\begin{array}{l}\mathrm{SiO}_{2} \sim 55 \\
\mathrm{Na}_{2} \mathrm{O} \sim 3 \\
\mathrm{MgO} \sim 2.5 \\
\mathrm{~K}_{2} \mathrm{O}>2.5\end{array}$ & & $-11.4 \%$ & $\begin{array}{l}\text { One single flow of } 13.4 \mathrm{~m} \text { thickness including F12 and } \\
\text { D7. } \\
\text { Within the A subgroup, this flow is more evolved } \\
\text { compared to A2. } \\
\text { Highest alkaline concentration in the LS. }\end{array}$ \\
\hline Flow unit A2 & $\begin{array}{l}\text { Glass (ca. } 90 \text { Vol.\%), minor } \\
\text { plag, cpx, and the only flow } \\
\text { unit crystallizing sanidine }\end{array}$ & $\begin{array}{l}\mathrm{SiO}_{2} \sim 51.5 \\
\mathrm{Na}_{2} \mathrm{O} \sim 3.2 \\
\mathrm{MgO} \sim 5.5 \\
\mathrm{TiO} \sim 1.3\end{array}$ & $\begin{array}{l}\text { Depleted in incompatible elements } \\
\text { like HFSE and REE compared to the } \\
\text { other units. }\end{array}$ & $-11.8 \% \circ)$ & $\begin{array}{l}\text { Regroups the initially individual flows F118, F119, and } \\
\text { F120. } \\
\text { A2 has the most primitive geochemistry of the } \\
\text { extrusive rocks sampled within the LS. }\end{array}$ \\
\hline Flow unit B1 & $\begin{array}{l}\text { Glassy (ca. } 90 \text { Vol.\% glass) } \\
\text { cordierite bearing, plag, and } \\
\text { opx crystallizing peperitic flow } \\
\text { unit }\end{array}$ & $\begin{array}{l}\mathrm{SiO}_{2} \sim 60 \text { to } 55 \\
\mathrm{Na}_{2} \mathrm{O} \approx 3 \\
\mathrm{~K}_{2} \mathrm{O} \approx 0.75 \\
\mathrm{Al}_{2} \mathrm{O}_{3} \approx 16\end{array}$ & $\begin{array}{l}\text { Rocks of this group show the } \\
\text { highest abundances of HFSE and } \\
\text { LREE }\end{array}$ & $-5.6 \%$ & $\begin{array}{l}\text { Flow unit B1 is } 13.8 \mathrm{~m} \text { thick and consists of the } \\
\text { formerly individually characterized flows F114, F115, } \\
\text { F116, and F117 due to its peperitic nature. }\end{array}$ \\
\hline $\begin{array}{l}\text { Flow unit } \\
\text { B2 }\end{array}$ & $\begin{array}{l}\text { Plag and opx crystallizing } \\
\text { glassy (in its upper part) and } \\
\text { porphyric (in its lowest part) } \\
\text { dacite lava flow }\end{array}$ & $\begin{array}{l}\mathrm{SiO}_{2} \sim 62 \text { to } 70 \\
\mathrm{MgO} \sim 0.4-1.7 \\
\mathrm{Al}_{2} \mathrm{O}_{3} \sim 15\end{array}$ & $\begin{array}{l}\mathrm{U} \approx 2.3-2.7 \mathrm{ppm} \\
\mathrm{Th}>11 \mathrm{ppm}\end{array}$ & $-6.4 \%$ & $\begin{array}{l}\text { One single massive flow of } 53 \text { m thickness including } \\
\text { F106, F107, F108, F109, F110, F111, F112, and F113. } \\
\text { This flow unit is the most evolved melt recovered } \\
\text { within the LS }\end{array}$ \\
\hline $\begin{array}{l}\text { Sills D5s and } \\
\text { D6s }\end{array}$ & Mafic tholeiitic sills & $\begin{array}{l}\text { D5s is the most } \\
\text { mafic unit within all } \\
\text { of the lower series } \\
(\mathrm{MgO} \sim 8.4) \text {. } \\
\text { D6s is slightly more } \\
\text { differentiated (MgO } \\
\sim 5.2 \text { ). }\end{array}$ & $\begin{array}{l}\text { REE geochemistry pointing toward } \\
\text { stronger depleted mantle source } \\
\text { compared to SDR and standard } \\
\text { North Atlantic }\end{array}$ & $-9 \%$ & $\begin{array}{l}\text { D5s }(18 \mathrm{~m}) \text { geochemistry is similar to B2 trend. } \\
\text { D6s }(1.4 \mathrm{~m}) \text { follows the differentiation trend of the } \\
\text { flow Units A1 and A2 }\end{array}$ \\
\hline $\begin{array}{l}\text { Sedimentary } \\
\text { units }\end{array}$ & $\begin{array}{l}\text { Volcaniclastic sediment units } \\
\text { (S48-47 and S43) of } \\
\text { non-welded tuff deposits. } \\
\text { Devitrified glass and abundant } \\
\text { quartz xenocrysts }\end{array}$ & $\begin{array}{l}\text { For S48 the } \\
\text { geochemical major } \\
\text { elements are similar } \\
\text { to B2 flow unit }\end{array}$ & & & $\begin{array}{l}\text { Combined sediment unit S47/S48 is interpreted as a } \\
\text { fallout ash layer in the upper section of S48 and a } \\
\text { non-welded ignimbrite in its lower part. Pumiceous } \\
\text { glass fragments including bubble walls and tubular } \\
\text { pumice are frequent in the central part of the unit }\end{array}$ \\
\hline
\end{tabular}

reflections (Figs. 4A and 5A). While flattening the seismic reflection profile (e.g., Fig. 5A) by using the K-Reflection as a flat horizontal surface, we have been able to get improved image of the internal reflection structures within the Lower Series Flows unit (Fig. 5B). Generally, the internal shape is disrupted and hummocky and usually shows parallel to subparallel reflections. Additional linear features have been identified and inferred to represent a part of the feeder dyke system of the SDR (Fig. 5B). The extent of dyke reflection along the Vøring Margin correlates the extent of the SDR and locally the Landward Flows. Generally, the SDR growth was accommodated by minor extensional faulting during magma intrusion, although such active fault systems are not systematically observed. The faults are used as magma conduits, hampering their identification on seismic profiles (see also Abdelmalak et al., 2015).

From the average energy attribute in seismic profiles, the Lower Series Flows represent a high reflected energy with discontinuous and thick features compared to the Inner SDR and underlying structures (Fig. 5C). The seismic average energy signature of the Lower Series Flows could be interpreted as the geophysical responses of lava flows and sill intrusions with interbedded sedimentary layers. The sediments are early Eocene in age for the Lower Series Flows. These discontinuous and thick features identified from the average energy attribute in seismic profile are confirmed by the core samples of Hole $642 \mathrm{E}$ showing volcanic units and thicker interbedded volcanosedimentary units in the Lower Series Flows (Lower Series in the ODP Hole 642E) compared to the SDR (the Upper Series) dominated by massive lava flows.

The K-Reflection identified at the base of the SDR is most clearly characterized by a negative in polarity reflection in the seismic data. This reflection has been petrologically linked with a $12 \mathrm{~m}$ thick volcano-sedimentary/tuffaceous unit (S43) separating the Upper and Lower Series in the ODP Hole 642E. Although its continuation toward the Vøring Escarpment has been documented (e.g., Skogseid and Eldholm, 1987), the position of the K-Reflection is commonly difficult to determine. We have re-mapped the extent of the K-Reflection on the basis of its strong negative signal in the seismic reflection data and on the basis of reflector truncation at the base of the Seaward-Dipping Wedge. The K-Reflection extends to more than $2100 \mathrm{~km}^{2}$ and deepens toward the continent-ocean transition as the result of tectonic and subsidence control during the construction of the SDR wedge (Fig. 6A).

From the seismic reflection imaging combined with the seismic average energy signature, we were able to determine the base of the Lower Series Flows facies unit. We used the top and the base of this facies unit described above and identified on the basis of seismic interpretation. The thickness of the Lower Series Flows facies unit ranges between 0.2 and $1.5 \mathrm{~km}$ with a clear ocean-ward increase in thickness (Fig. 6B).

\section{The Lower Series Flows lithology and petrology}

The upper $130 \mathrm{~m}$ of the Lower Series Flows has been drilled and sampled in the ODP Hole 642E (the so-called Lower Series in the ODP report, Eldholm et al. (1987)). The recovered igneous rock succession includes exceptional glassy dacitic lavas as well as basaltic andesitic lava flows interbedded with thick volcano-sedimentary deposits and intruded tholeiitic sills (Parson et al., 1989; Viereck et al., 1989; Meyer et al., 2009a; Fig. 2). We follow here Meyer et al. (2009a), who used an updated lithological subdivision for the Lower Series based on new petrographic and geochemical observations. During their investigation, these authors deduced that the recovered Lower Series lithology would consists of two major igneous groups A and B (previously defined by Parson et al., 1989), which can be further classified into distinct felsic lava flow units A1, A2, B1, and B2. Initially defined smaller individual flows have been reinterpreted as crystallinity variations, shear planes, and peperitic interactions within the four major lava flow units (Table 2). 

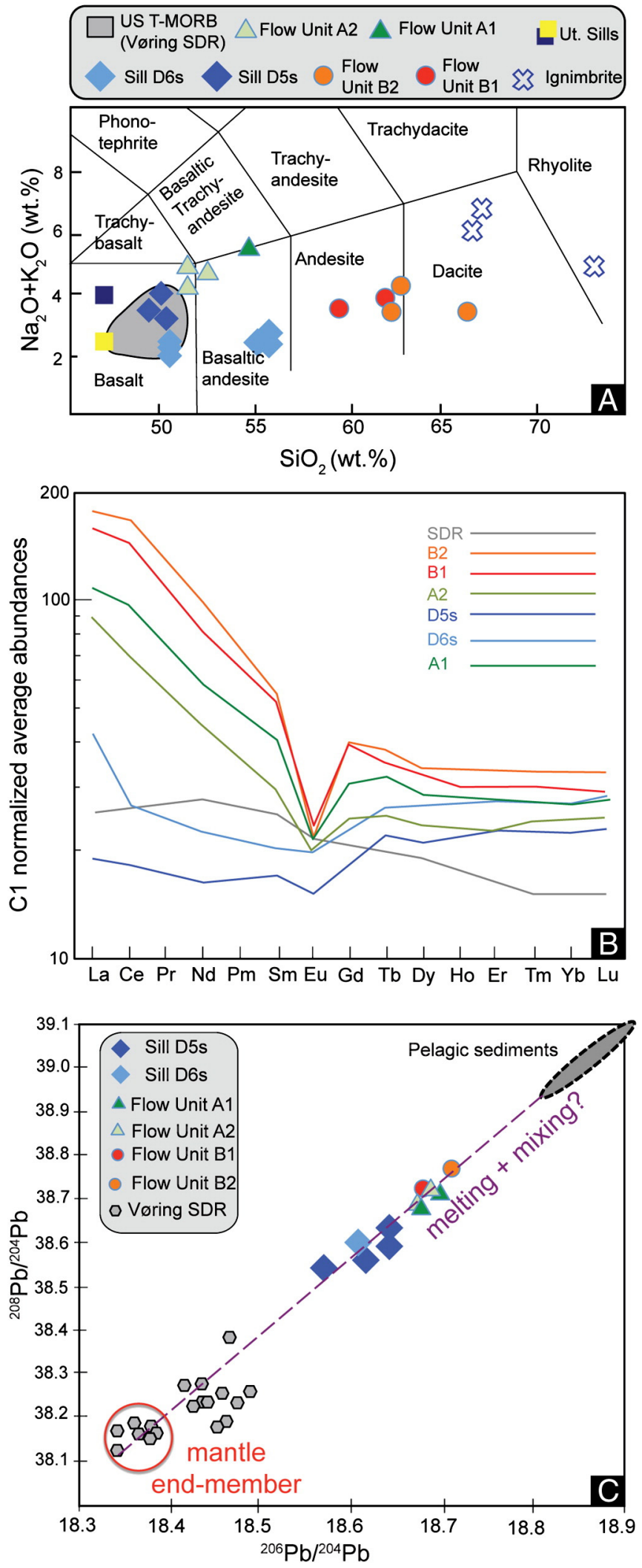

Fig. 7. (A) Total alkali-silica (TAS) diagram used to illustrate the composition of the ODP Hole 642E magma. The Utgaard High sills are also plotted in the diagram. (B) Average rare earth element patterns of the Lower Series Flows and the SDR. The spoon shape of the sills D5s and D6s indicate a strongly depleted mantle origin. Average from Meyer et al. (2009a) and normalizing values from McDonough and Sun (1995). (C) ${ }^{206} \mathrm{~Pb} /{ }^{204} \mathrm{~Pb}$ vs. ${ }^{208} \mathrm{~Pb} /{ }^{204} \mathrm{~Pb}$ isotope ratios for the different units of the Lower Series Flows (data from Meyer et al., 2009a). Ut. Sills: Utgard High sills (data from Neumann et al., 2013).

\subsection{Flow unit $A 1$}

The base of the recovered/sampled Lower Series is represented by the flow unit (A1). This single subaqueous flow of $13.4 \mathrm{~m}$ thickness has a porphyric texture with a glassy (ca. 25 vol.\%) matrix and plagioclase, orthopyroxene, and clinopyroxene phenocrysts. With a content of around 3 wt.\% $\mathrm{Na}_{2} \mathrm{O}$ and $>2.5 \mathrm{wt} . \% \mathrm{~K}_{2} \mathrm{O}$, flow unit $\mathrm{A} 1$ has the highest alkaline concentrations within the lower series lithology (Fig. 7A). Within the A subgroup, this flow is more evolved compared to $\mathrm{A} 2$, with a $\mathrm{MgO}$ abundance of around $2.5 \mathrm{wt} . \%$ and $55 \mathrm{wt} . \% \mathrm{SiO}_{2}$. The $1.8 \mathrm{~m}$ thick sediment S49 caps this flow at the top (Fig. 2). A calcite-filled fracture within the lowest part of the recovered flow has provided a $\delta^{13} \mathrm{C}_{\mathrm{PDB}}$ of $-11.4 \%$ (Love et al., 1989), which has to be interpreted as a mixture of light organic carbon with ambient mantle carbon (Table 2).

\subsection{Flow unit A2}

This flow unit regroups the initially individual flows F118, F119, and F120 as all of these "flows" have an identical geochemistry with an $\mathrm{SiO}_{2}$ content of 51.5 wt.\%, 1.3 wt.\% TiO, 3.2 wt.\% $\mathrm{Na}_{2} \mathrm{O}$, and $5.5 \mathrm{wt} . \% \mathrm{MgO}$. Due to this geochemical similarity and an identical petrography (ca. 90 vol.\% glass, minor plagioclase, clinopyroxene, and the only flow unit crystallizing sanidine), these formerly interpreted individual flows can be regrouped into a single $11.2 \mathrm{~m}$ thick basaltic andesitic flow unit and/or monogenetic successive flows. In analogy to the A1 flow unit, A2 has significantly higher alkaline contents compared to the B subgroup but is notably less evolved compared to the underlying A1. The A2 flow unit has the most primitive geochemistry of the extrusive rocks sampled within the Lower Series (Table 2). Compared to the other flow units within the Lower Series, this flow is depleted in incompatible elements like HFSE (high field strength elements) and REE (rare earth elements) (Fig. 7B) (Meyer et al., 2009a). The lightest C-isotope data $\left(\delta^{13} C_{\mathrm{PDB}}-11.8 \%\right.$ ) within the Vøring igneous rock successions have been measured from a calcite-filled vesicle within, the lowest part, of this flow unit (Love et al., 1989). This stable isotope data points also toward a mixture of mantle and organic carbon in the source.

\subsection{Flow unit B1}

Flow unit B1 is $13.8 \mathrm{~m}$ thick and consists of the formerly individually characterized flows F114, F115, F116, and F117 are now interpreted as a glassy (ca. 90 vol.\% glass) peperitic cordierite bearing, plagioclase, and orthopyroxene crystallizing flow unit (Table 2). Macroscopically, this magma interacted during its emplacement with wet sediments. Similar as for the above described flow unit, the formerly interpreted different flows can so be simplistically described as the same magma intruding/ extruding a congruent wet silt to sandy sedimentary package, of terrigenous, marine and volcanoclastic components (S44, S45, and S46). Baked contacts between melt and sediments have been observed when contacts have been cored and recovered. Due to interactions with the wet sediments of different grain size, the massif glassy dacite flow with a perthitic texture is hydrothermally altered in areas with a high sediment/melt ratio. Consequently, this flow unit is mineralogically indistinguishable and reports variations in $\mathrm{SiO}_{2}$ content, partly due to alteration. Rocks of this group show the highest contents in HFSE and LREE (light rare earth elements) (Meyer et al., 2009a). The geochemical content within this peperitic flow varies mainly for $\mathrm{SiO}_{2}$ between 60 and 55 wt.\%, with more constant $\mathrm{Na}_{2} \mathrm{O} \approx 3$ wt.\%, $\mathrm{K}_{2} \mathrm{O} \approx 0.75$ wt.\%, and $\mathrm{Al}_{2} \mathrm{O}_{3} \approx 16$ wt.\% contents. Available $\delta^{13} \mathrm{C}$ values of $-5.6 \%$ (Love et al., 1989 ) point towards slightly lighter carbon isotopic composition compared to the Vøring SDRs rocks $\left(\delta^{13} \mathrm{C}\right.$ values around $-4 \%$ ). As this peperitic flow shows strongest macroscopic in-situ interactions with the paleo-surface sediments and a more normal $C$ isotopic composition, the isotopic data measured within the A1 and A2 flow units seem to represent interactions with initially organic rich material deeper in the crust. 


\subsection{Flow Unit B2}

The upper most flow unit of the Lower Series is a massive $53.5 \mathrm{~m}$ thick subaqueous cordierite bearing plagioclase and orthopyroxene crystallizing glassy (in its upper part) and porphyric (in its lowest part) dacitic lava flow. The initially defined boundaries in between the geochemically similar F106, F107, F108, F109, F110, F111, F112, and F113 (Fig. 2B) have to be understood as shear planes separating internal zones of distinctive crystallinity and hydrothermal alteration/devitrification within one single flow. Meyer et al. (2009a) showed that the initially described evolved dyke D4 is geochemically indistinguishable with the overlying flows F106 to F113 and represents the 21 m thick aphanitic base of this massive lava flow (Table 2). Instead of an intruding separate dyke with exactly the same geochemistry, we integrated this part into the geochemically identical flow. This flow unit is the most evolved rock succession recovered within the Lower Series Flows (62 to 70 wt.\% $\mathrm{SiO}_{2}$; ca. 15 wt.\% $\mathrm{Al}_{2} \mathrm{O}_{3} ; 0.4-1.7$ wt.\% $\mathrm{MgO}$; with 2.3-2.7 ppm U; and $>11 \mathrm{ppm} \mathrm{Th}$ ). This flow lithology has a reported filled vesicle with a normal mantle magmatic $\delta^{13} C_{\mathrm{PDB}}$ of $-6.4 \%$ o compared to the organic $<-11 \%$ o (Love et al., 1989) within the flow units $\mathrm{A} 1$ and $\mathrm{A} 2$.
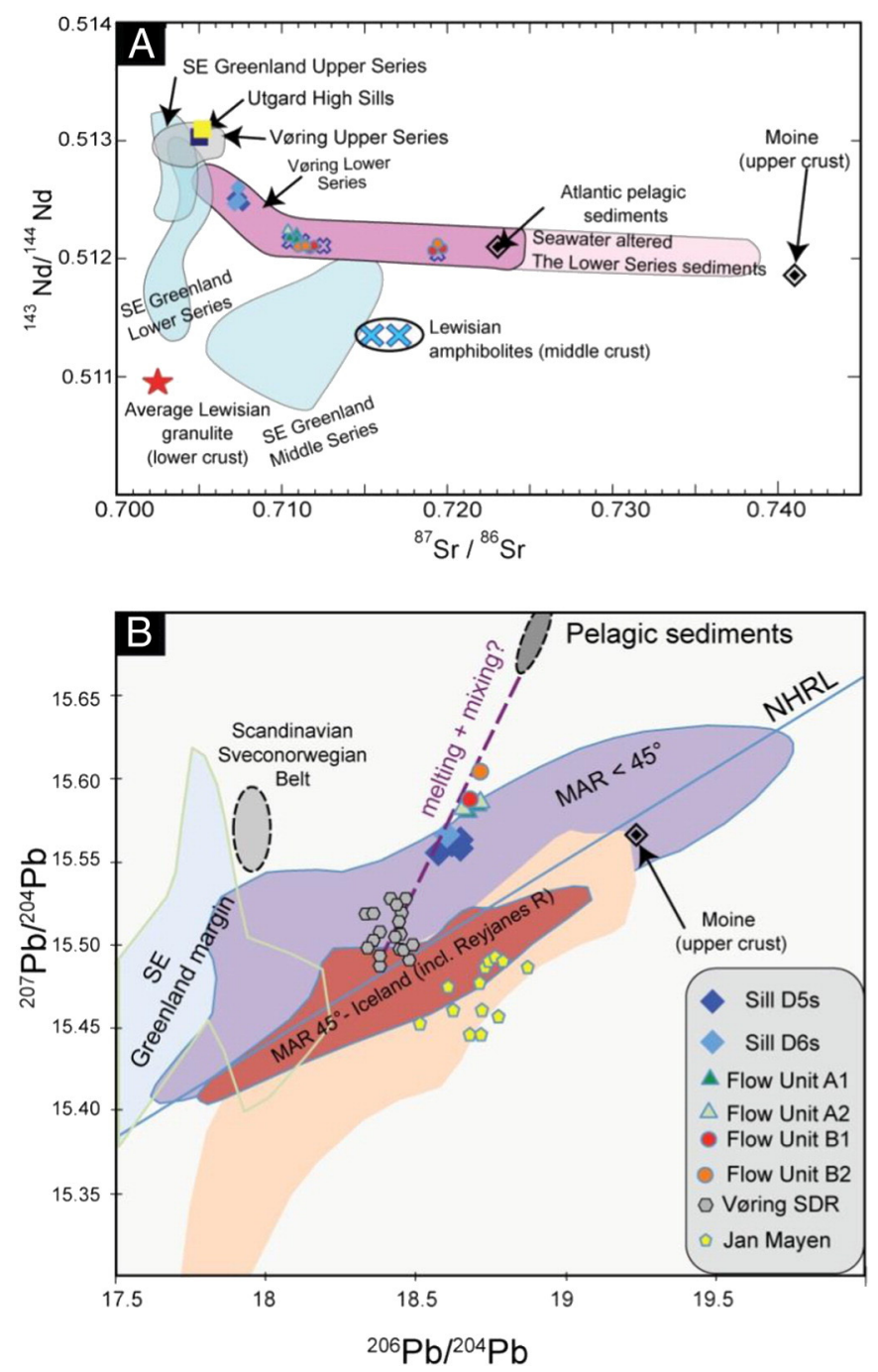

Fig. 8. (A) Comparison of the $143 \mathrm{Nd} / 144 \mathrm{Nd}$ vs. ${ }^{87} \mathrm{Sr} /{ }^{86} \mathrm{Sr}$ isotope ratios of the Lower Series Flows with available data from the North Atlantic area. (B) Comparison of the ${ }^{206} \mathrm{~Pb} /{ }^{204} \mathrm{~Pb}$ vs. ${ }^{207} \mathrm{~Pb} /{ }^{204} \mathrm{~Pb}$ isotope ratios of the Lower Series Flows with available data from the North Atlantic area. NHRL: Northern Hemisphere Reference Line; MAR: Mid-Atlantic Ridge.

\subsection{Sills D5s and D6s}

Distinct mafic "dykes" D5 and D6 reported in the initial core descriptions are reinterpreted in this study as sills and named D5s and D6s. This re-interpretation is based on the fact that Meyer et al. (2009a) presented that these depleted igneous rocks, with a characteristic spoon shaped REE pattern, can petrogenetically not be directly related to the SDRs tholeiites and their mantle source (Fig. 7B, Table 2). The major element geochemistry of the upper part of this massive sill follows a trend toward higher Si content with no influence on the alkaline geochemistry, similar to the intruded B1 trend (Fig. 7A). In contrast to this melt evolution and the Vøring SDRs tholeiites, sill D6s follow the differentiation trend of the flow Units A1 and A2 toward higher alkaline concentrations with higher Si content. A $\delta^{13} C_{\mathrm{PDB}}$ of $-9 \%$ (Love et al., 1989) measured within a fracture of this sill points also to the in situ interaction of the sill magma with these flow units $\left(\delta^{13} C_{\mathrm{PDB}}<-11 \%\right)$ and/or with the same organic rich crustal source during magma transport. Both sills are identical in trace element geochemistry but systematically different compared to the felsic flow units that they intrude. Based on radiogenic isotopes, these sills can be interpreted as binary mixtures between the felsic crustal anatectic rocks and the Vøring SDRs melts, but with an REE geochemistry pointing toward a much more depleted mantle source being tapped. Similar LREE depleted melts are highly uncommon in the NE Atlantic and have recently been observed only along the Jan. Mayen Ridge (Meyer et al., submitted for publication).

\subsection{Sedimentary deposits}

Both major Lower Series igneous flow groups (A and B) are always covered by thick volcanoclastic sediments (S48-47 and S43) (Fig. 2B). The stratigraphy of S48 consists of non-welded tuff deposits overlain by a fallout sequence. The $13 \mathrm{~m}$ thick S43 is identified on the top of the Lower Series and directly underlays the SDRs at the Vøring Margin. The transition from the Lower Series into the SDRs is most likely a disconformity within this volcanoclastic deposit. This erosion unconformity separates compacted and well-graded sediments at the lower part from upper uncompacted tuffite sediments.

\section{The Lower Series Flows geochemistry}

The total alkali versus silica (TAS) classification diagram (Le Bas et al., 1986) points toward two different melt evolutions within the Lower Series. All flows within the Lower Series Flows are aluminia oversaturated, with a peraluminous to strongly peraluminous chemistry (Meyer et al., 2009a) (Fig. 7A). The peraluminous character of the Lower Series melts is best illustrated by the molecular ratios of $\mathrm{Al}_{2} \mathrm{O}_{3}$ / $\left(\mathrm{Na}_{2} \mathrm{O}+\mathrm{K}_{2} \mathrm{O}\right): 1.5$ to 3.2 and $\mathrm{Al}_{2} \mathrm{O}_{3} \mathrm{l} /\left(\mathrm{CaO}+\mathrm{Na}_{2} \mathrm{O}+\mathrm{K}_{2} \mathrm{O}\right): 1.2$ to 1.86 within the discrimination diagram of Maniar and Piccoli (1989). However, as $\mathrm{Si}$, Na, and $\mathrm{K}$ can be mobilized from glass during hydrothermal alteration, the presence of primary crystallized cordierite phenocrysts within the B1 and B2 glassy flow units clearly proves the initial aluminia saturation chemistry within the Lower Series melts. This strongly peraluminous geochemistry demonstrates that these magmas are $\mathrm{S}$ (sedimentary)-type granitic melts. S-type granitic magmas are partial melting products of sedimentary source rocks composed partly of (metamorphosed) clay minerals (Chappell and White, 1992). As a result, dehydration crustal anataxis, due to an increased geothermal gradient within a volatile bearing lithology, would be the best scenario to produce the sampled Lower Series Flows crustal melts.

However, due to the more mafic geochemistry of the basaltic andesitic flows, magma mixing between the asthenospheric melts and the crustal melts must have occurred prior to the emplacement. This mixing trend is recorded in the major element geochemistry of the lowest basaltic andesitic A1 and A2, who increase equally their alkali content with increasing silica, in contrast to the overlying dacitic flows, who do not show any increase in $\mathrm{Na}$ and $\mathrm{K}$ with $\mathrm{Si}$. Interestingly, the sills 
intruding these flow units show the same evolution characteristics as their respectively intruded lithologies (Fig. 7A). The present data set is however still too small to distinguish if these trends within the sills are in situ interactions with the intruded lithologies, and/or if these signatures would be source related and pointing toward an identical petrogenetic history as the intruded rocks. However, the similarity in trace element and radiogenic isotopes between the two sills and the intruded lithologies points toward in situ interactions of the intruding melts with the penetrated lithologies.

High-quality $\mathrm{Pb}$ isotopic compositions of the ODP Hole 642E rocks are plotted in Figs. 7C and 8B. The Lower Series Flows rock samples have significantly higher radiogenic initial ${ }^{206} \mathrm{~Pb} /{ }^{204} \mathrm{~Pb},{ }^{207} \mathrm{~Pb} /{ }^{204} \mathrm{~Pb}$, and ${ }^{208} \mathrm{~Pb} /{ }^{204} \mathrm{~Pb}$ ratios compared to the most primitive Vøring SDRs melts (Figs. 7C and 8B). The upper continental crust involved at the Vøring Margin has a $\mathrm{Pb}$ isotope geochemistry similar to anthropogenically uncontaminated North Atlantic pelagic sediments (e.g., Hamelin et al., 1990) unlike other potential and/or proposed crustal source lithologies like Moine shiste source (Meyer et al., 2009b) and definitely different to lower and/or middle continental crustal rocks involved at the SE Greenland margin (Fitton et al., 1998) (Fig. 8B).

Pelagic sediment, as crustal melting end member, would not only be responsible for the measured $\mathrm{Pb}$ isotope geochemistry but also be able to explain the observed trace element abundances. The high concentrations of the incompatible elements Th (12-17 ppm, Meyer et al., 2009a, 2009b) and U (2.7-3.5 ppm, Meyer et al., 2009a, 2009b) within the isotopically most pelagic-like pure crustal anatectic flow Unit B2 suggest either low melting degrees, which would however be contradictory to the major element geochemistry, and/or a higher concentration of these elements in the melting source rock. Marine pelagic clay has an average Th concentration of $13 \mathrm{ppm}$ and $2.6 \mathrm{ppm}$ for $U(\mathrm{Li}, 1991)$ and hence further supports a significant pelagic sediment proportion within the upper continental crustal source during melting. It can be concluded that the isotope geochemistry of the Lower Series rocks points to primitive T-MORB-like asthenospheric melts (Meyer et al., 2009a), interacting with highly radiogenic pelagic upper crustal sedimentary rocks. Such mantle melt-crust interactions could either be based on heat transfer and dehydration partial melting of the surrounding crust (Lower Series dacites) and/or by magma mingling between crustal melts and asthenospheric melts (Lower Series basaltic andesites).

Alternatively, heat transfer due to the loss of continental crust into the asthenosphere, as described in Esedo et al. (2012) and later confirmed for the opening of the Central Atlantic (Meyer and van Wijk, 2015), could result in pure crustal melts due to an increased thermal difference between upper continental crust and new underlying asthenosphere. The more mafic basaltic andesitic melts would in such a scenario represent pure crustal melts mixing with decompression melts of the asthenospheric mantle (e.g., Meyer and van Wijk, 2015). The continental melting source material can be further constrained by available carbon isotope data from vesicles of the Lower Series Flows (cf. Table 2). These data are all considerably isotopically lighter compared to the mantle and advocate so for significant organic carbon content within the melting source sediments.

\section{Discussion}

\subsection{Nature of the Lower Series Flows}

Large igneous provinces are defined as highly voluminous mafic igneous rock successions emplaced within a short geological time span as continental flood basalt provinces, oceanic plateaus, and volcanic rifted margins. However, silicic volcanic rock sequences have been reported from several LIPs like Karoo, Parana-Etendeka, Deccan LIP (Bryan et al., 2002), including the North Atlantic Igneous Province (NAIP) (Meyer et al., 2009a, 2009b). While the mafic melts are able to cast light on mantle source, the silicic magmas allow the definition of melt-rock interactions processes during the LIP emplacement. In contrast to late silicic activities recorded in other LIPs (Bryan et al., 2002), the $\mathrm{SiO}_{2}$-rich melts of the Vøring volcanic margin erupted in the earlier stage of the LIP and SDR formation (e.g., Saunders et al., 1997; Meyer et al., 2009b).

$\mathrm{Pb}$ isotopic variations of the mafic SDRs melts $\left({ }^{206} \mathrm{~Pb} /{ }^{204} \mathrm{~Pb} \approx 18.45\right.$; ${ }^{207} \mathrm{~Pb} /{ }^{204} \mathrm{~Pb} \approx 15.5$; and ${ }^{208} \mathrm{~Pb} /{ }^{204} \mathrm{~Pb} \approx 38.25$ ) (Figs. $7 \mathrm{C}$ and $8 \mathrm{~B}$ ) show that the involved mantle source has a higher radiogenic $\mathrm{Pb}$ isotope composition compared to initial SE Greenland mantle melts. The Vøring SDRs melts are even significantly more radiogenic compared to the Ellam and Stuart (2000) proposed North Atlantic End-Member (NAEM) $\left({ }^{206} \mathrm{~Pb} /{ }^{204} \mathrm{~Pb} \approx 17.5 ;{ }^{207} \mathrm{~Pb} /{ }^{204} \mathrm{~Pb} \approx 15.4 ;\right.$ and $\left.{ }^{208} \mathrm{~Pb} /{ }^{204} \mathrm{~Pb} \approx 37.4\right)$, but still significantly less radiogenic than the Lower Series Flows. The sampled sills D5s and D6s are displaced from the Vøring SDRs melts toward the very radiogenic Lower Series Flows and confirm their mixture between the crustal material and the SDRs mantle melts.

Most of the Lower Series lavas cluster together around ${ }^{87} \mathrm{Sr} /{ }^{86} \mathrm{Sr}=$ 0.71 and ${ }^{143} \mathrm{Nd} /{ }^{144} \mathrm{Nd}=0.5122$; this is significantly outside the accepted range of pristine mantle ratios (Meyer et al., 2009a). In addition, the $\mathrm{Pb}$ isotope characteristics are a prove of the S-type crustal anatectic nature of these sub-SDRs rocks and present a major indication of a strong involvement of radiogenic crustal material in the petrogenesis of these rocks. In contrast to the lower and middle crustal contaminated magmas at the SE Greenland margin and the British Tertiary Igneous province, the Lower Series at the Vøring Margin point to interactions restricted to upper crustal material (Meyer et al., 2009a) (Fig. 8A).

Based on Sr and Nd isotopic data, Meyer et al. (2009b) suggested that metasedimentary rocks, similar to the Moine Supergroup, where likely to be the crustal anatectic melting source for the Lower Series Flows. However, plotting Moine schist $\mathrm{Pb}$ isotope data from Geldmacher et al. (2002) $\left({ }^{206} \mathrm{~Pb} /{ }^{204} \mathrm{~Pb}=19.27 ;{ }^{207} \mathrm{~Pb} /{ }^{204} \mathrm{~Pb}=15.56\right.$; and ${ }^{208} \mathrm{~Pb} /{ }^{204} \mathrm{~Pb}=38.82$ ) does not define a potential mixing line end member of the Vøring mantle source and the Lower Series crustal melts. Thus, a Moine-like rock lithology seems to be unlikely. We suggest here that based on the $\mathrm{Pb}$ isotopes, the upper crustal melting source consist for a large part of pelagic sediments similar to anthropogenically uncontaminated North Atlantic sediments (e.g., Hamelin et al., 1990). A high content of such pelagic sediment in the melting source is also able to explain the observed Sr and Nd isotope variations and high Th, U concentrations within the peraluminous Vøring crustal melts. The reported ${ }^{13} \mathrm{C}$-depleted carbon isotope values within vesicles of the Lower Series Flows (Love et al., 1989) further point toward a significant organic carbon content within the melting crustal segment.

\subsection{Emplacement age of the Lower Series Flows}

In the Vøring Basin, exploration well 6607/5-2 at the Utgard High (Fig. 3) penetrated two microgabbro sills intruded into Upper Cretaceous mudstone and sandstone lithologies (Berndt et al., 2000). The sill geochemistry (Neumann et al., 2013) shows that these magmas are significantly more differentiated compared to the already fractionated Vøring SDR melts (Viereck et al., 1989). The ${ }^{87} \mathrm{Sr} /{ }^{86} \mathrm{Sr}$ and ${ }^{143} \mathrm{Nd} /{ }^{144} \mathrm{Nd}$ ratios of the Utgard High sills and the Vøring Upper Series (the SDR seismic facies unit), however, overlap and point toward a same

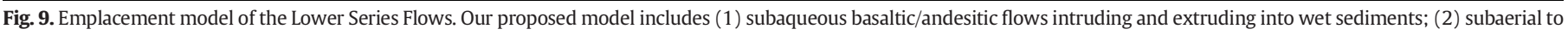

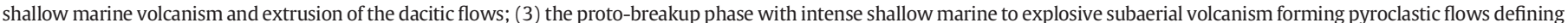

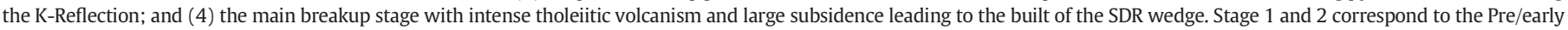

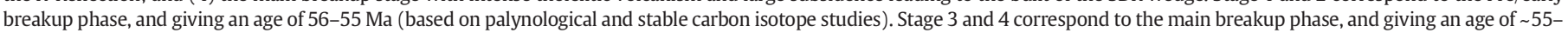
$53 \mathrm{Ma}$. 


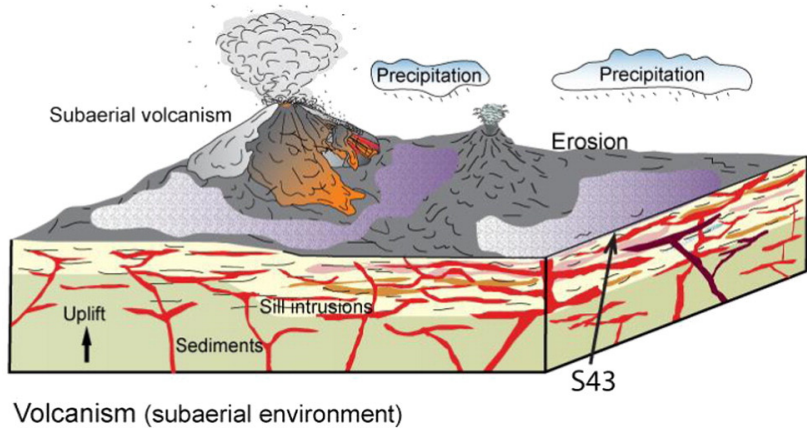

Volcanism (subaerial environment)

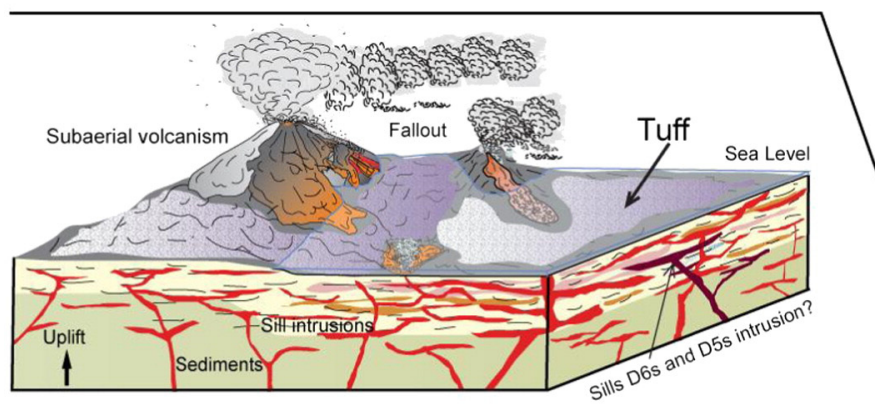

Explosive volcanism (subaqueous environment ?)

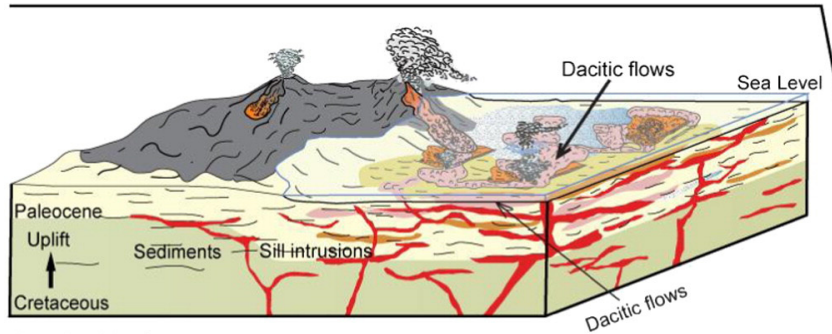

(b): dacitic flows (subaqueous environment)

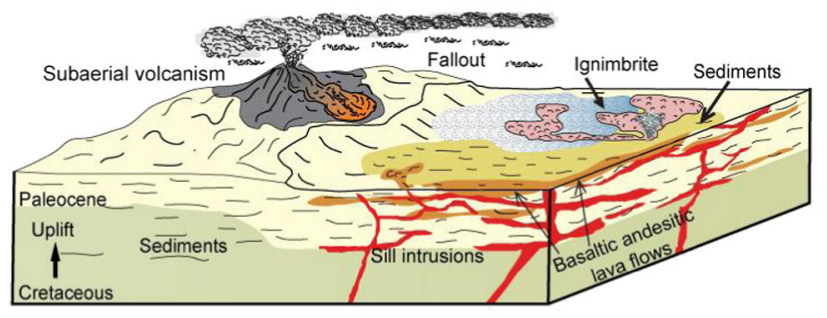

(a): explosive silicic volcanism (subaerial environment)

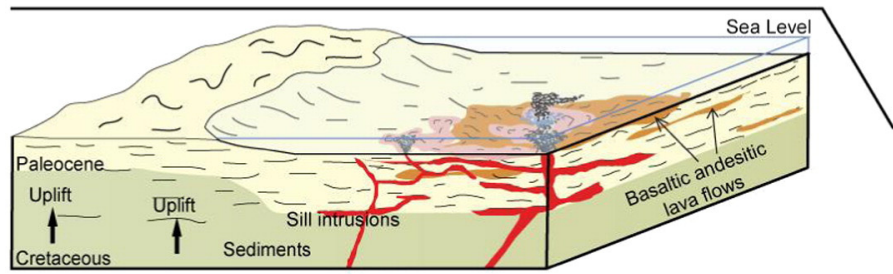

(b): basaltic andesitic flows (subaqueous environment)

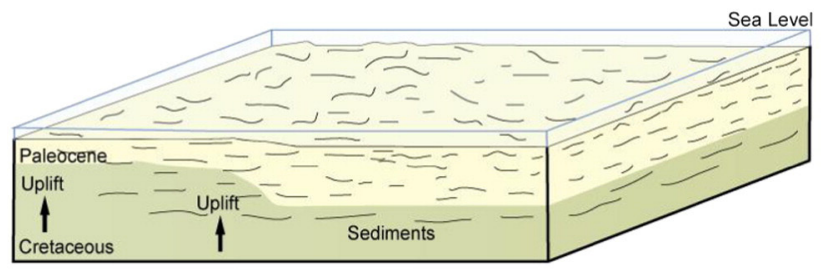

(a): sedimentary basin (subaqueous environment)
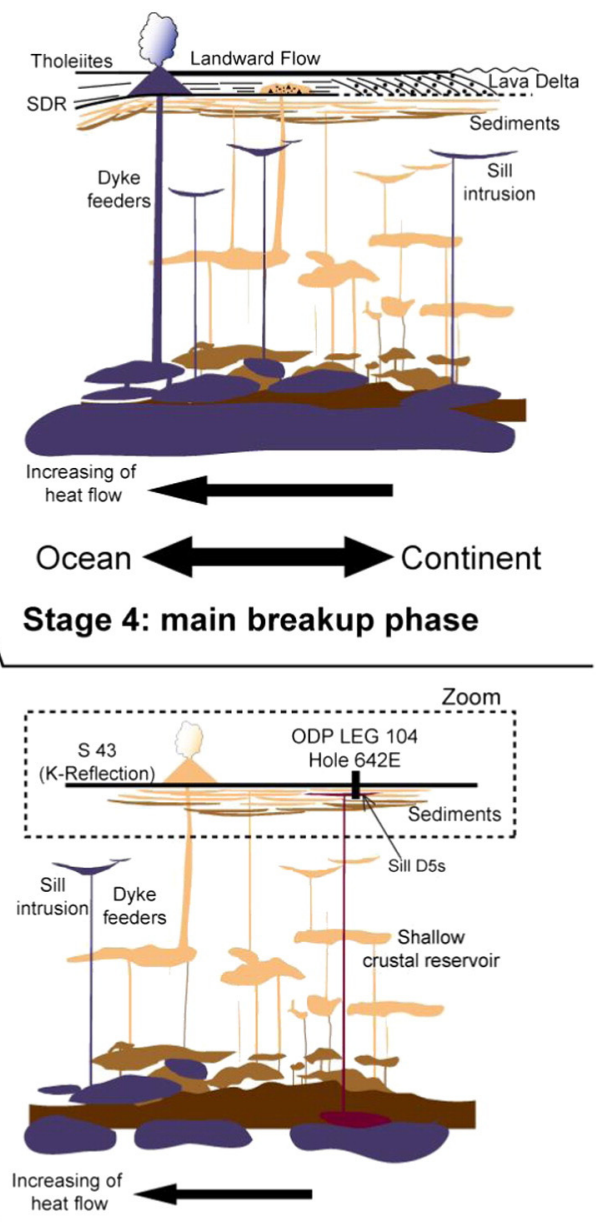

Stage 3: proto-breakup phase

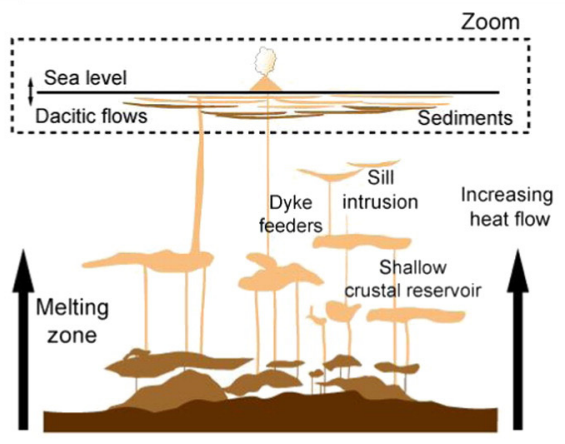

Stage 2: dacitic flows

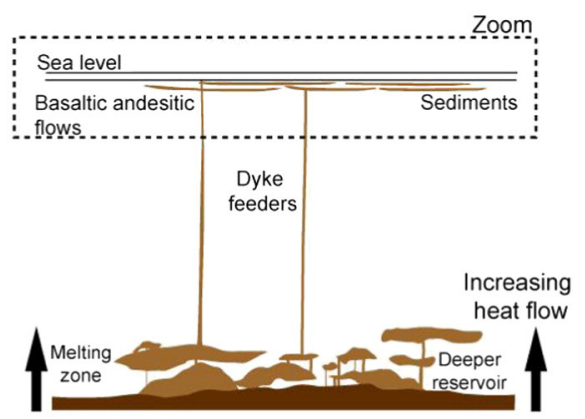

Stage 1: basaltic andesitic flows 
asthenospheric mantle-melting source (Fig. 8A). Radiometric dating provided $\mathrm{U}-\mathrm{Pb}$ zircon refined ages of $55.66 \pm 0.3$ and $56.36 \pm 0.4 \mathrm{Ma}$ for these intrusions (Planke and Corfu, 2010; Neumann et al., 2013). These results are consistent with the widely believed ages of the early breakup volcanism stage at the Vøring Margin.

We confirm the occurrence of Apectodinium augustum in the sedimentary unit of the Lower Series Flows, as previously reported by Boulter and Manum (1989). Although this species is a marker for the PETM (Schmitz et al., 2004; Sluijs et al., 2006), we consider their occurrence to represent reworked specimens based on incompatible high bulk organic $\delta^{13} \mathrm{C}$ values of the same samples (see Chapter 5 ). The evidence from biostratigraphy and carbon isotope ratios thus indicates that the emplacement of the Lower Series at Hole 642E postdates the PETM and is early Eocene in age.

These new stratigraphic results are in conflict with interpretations of the magnetic polarity distribution of the Lower Series Flows. This shows a normal polarity zone which was correlated with the upper Paleocene Chron C25n (Schönharting and Abrahamsen, 1989) (57.6 and $57.01 \mathrm{Ma}$ ). It may be more likely that widespread remagnetisation effects due to the sill intrusions considerably affected the magnetic signal by heating effect. Our chemo-biostratigraphic constraints imply an age younger than the Paleocene-Eocene boundary. However, similar to Boulter and Manum (1989) we did not record dinoflagellate cyst markers that are typical for such young strata. From the available radiometric ages for the Lower Series igneous rocks the most significant and accurate age is provided by Sinton et al. (1998) giving crystallization age of 56-55 Ma even if their results were "somewhat disturbed".

The Upper Series, directly above the Lower Series, shows a reversed magnetic polarity acquired during rapid extrusion correlated within magnetic polarity Chron C $24 \mathrm{r}$ (i.e., between $~ 57$ and -54 Ma according to Gradstein et al. (2012) time scale). The Upper Series has been linked to the uppermost nanoplankton zone NP9 and the NP10 zone indicating an age ranging between 55 and $54 \mathrm{Ma}$.

Since the emplacement of the Lower Series must postdate the PETM and probably the radiometric age of 55-56 Ma obtained by Sinton et al. (1998), we speculate that reworking of A. augustum into the Lower Series could be geologically rapid, possibly less than $1 \mathrm{Ma}$. An age spanning the first million years of the Eocene is consistent with our new dinoflagellate cyst and $\delta^{13} \mathrm{C}$ results.

This age represents the latest extensional stage preceding the main volcanic event and breakup of the Vøring Margin. Nevertheless, the precise age of the Lower Series Flows needs to be confirmed by new accurate and additional high-resolution radiometric dating. The new age defined on the basis of palynological and $\delta^{13} \mathrm{C}_{\mathrm{TOC}}$ analyses shows that the transition between the pre-breakup ( $\sim 56-55 \mathrm{Ma})$ to the breakup stage in the Vøring Margin ( 55-53 Ma) occurred in a very short time. Our results show that the breakup process in the Vøring Margin did not happen at the Paleocene-Eocene transition but during the earliest Eocene.

\subsection{Nature of the K-Reflection}

The K-Reflection located below the Inner SDR wedge deepens progressively toward the oceanic domain (Fig. 3). Mutter et al. (1982) considered the continent-ocean boundary (COB) at/or close to the Vøring Escarpment, and interpreted the K-Reflection as a dyke-lava transition within the oceanic crust. On the other hand, Hinz et al. $(1982,1984)$ placed the COB further west, near the seaward edge of the lowermost part of the dipping reflectors, and the K-Reflection was interpreted as a potential upper Mesozoic to lower Cenozoic surface.

Skogseid and Eldholm (1987) argued that the entire volcanic sequences above the K-Reflection were caused by subaerial seafloor spreading, and that the flow properties of the basaltic melt allowed the lava to flow over large areas of neighboring thinned continental crust. They located the COB just west of the K-Reflection termination, below the innermost part of the seaward-dipping wedge.
For Planke and Eldholm (1994), the K-Reflection corresponds to the base of the Seaward-Dipping Reflector sequences rather than a transition between the Upper and the Lower Series. They correlate the KReflection with a flows in the lower part of the Upper Series basalt. For these authors, the laterally varying seismic character and poor continuity below K-Reflection suggest that the oldest basaltic lavas rest on a terrain of breakup rocks covered by dacitic lavas.

In this study, we show that the significance of the K-Reflection is somewhat different than what had been postulated before. The KReflection corresponds to the S43 volcanoclastic unit of tuff deposited in a transitional marine to subaerial environment. The extent of the KReflection corresponds to the extent of the ash and pyroclastic flow material deposited during explosive subaerial to shallow marine volcanic events. The deepening of this strong reflection toward the ocean is due to the tectonic tilting of the SDR wedge. Following Skogseid and Eldholm (1987) and Planke and Eldholm (1994), we assume that the continent-ocean boundary is preferentially located at the seaward termination of the K-Reflection.

\subsection{Emplacement model}

The Lower Series Flows seismic unit is considered to be a transitional facies unit between normal syn-rift sedimentation to the volcanic margin stage. The Lower Series Flows characterize the pre-breakup volcanostratigraphic interaction. Samples from ODP Hole 642E core stratigraphy are characterized by intense hydrothermal alteration and devitrification, which are separated by shear planes. The devitrified glassy flows suggest a subaqueous depositional environment (or interaction with shallow and wet sediments), while the ignimbrite layers are characteristic of subaerial environment. The geochemistry composition of this facies is in agreement with crustal melts and indicative of sediment assimilation and reports so a high degree of interaction between asthenospheric mantle melts and sedimentary rocks. On the Vøring Marginal High, the nature of rocks below the Lower Series Flows remains unclear since the seismic signal is obscured by the volcanic rocks. We have to emphasis that several strong reflections are identified and interpreted as sill complex beneath the lava flows (Figs. 3, 4, and 5). Such sill intrusions are typically characterized by high-amplitude and abrupt termination and sometimes saucer-shaped geometry (e.g., Planke et al., 2005, 2015). This observation implies the presence and preservation of sub-basalt basins below the Lower Series Flows in the Vøring Marginal High (Abdelmalak et al., 2015, submitted for publication). Nevertheless, neither age nor thickness of the sedimentary strata could be precisely determined. However, based on the known stratigraphy of the outer Vøring Basin described nearby the volcanic domain, they may contain a certain amount of Cretaceous to Paleocene sedimentary rocks (e.g., Gernigon et al., 2003; Ren et al., 2003).

Based on sub-basalt seismic imaging constraints, combined with petrological, geochemical observations, and available age data for the Lower Series Flows, we present a plausible and coherent emplacement model for this seismic facies unit. This new emplacement model illustrates the onset of breakup in the Vøring Margin. The following tectono-volcanic stages are proposed:

\subsubsection{Stage 1: basaltic andesitic flows}

As drilling stopped within the basaltic andesitic flow unit, little is known prior to the eruption of these crustal anatectic melts. The prevolcanic late Cretaceous-Paleocene topography is illustrated as Stage 1 (a) in Fig. 9. During this period, the outer Vøring Basin was characterized by low-angle normal faulting, subsidence, syn-rift sedimentation, and local uplift (Gernigon et al., 2003; Ren et al., 2003). From the upper Cretaceous to the upper Paleocene (Danian/early Thanetian: 66-59 Ma), a regional uplift event is recorded both in the Vøring Basin and entire NE Atlantic (Brekke et al., 2001). This uplift has been correlated with upwelling hot mantle and was responsible for a dramatic shallowing of the outer Vøring Basin and the emergence and local 
erosion of the pre-existing Cretaceous highs (e.g., Gjallar Ridge) (Brekke et al., 2001; Ren et al., 2003). The emplacement of sub-crustal magmatism possibly triggered a pulse of lithospheric thinning due to strain localization of the deformation as suggested by both analog (Callot et al., 2001, 2002) and numerical modeling (Yamasaki and Gernigon, 2009). Combined with the relative thermal effects of crustal intrusions, the enhanced crustal geothermal gradient, directly and/or indirectly initiated by the nascent magmatism, was locally enough to initiate hydrous anatexis of the pre-existing upper crustal lithologies. From the isotopic ratios results (Fig. 8A), we noticed that no interaction with sub-continental lithospheric material or lower crustal material is recorded within the melts in the Lower Series Flows. The Pb isotopic geochemistry confirms the strong interaction of mantle melts with sediments and/or upper crustal rocks. Esedo et al. (2012) described that lithospheric removal prior to the breakup is an important process prior to continental fragmentation. Meyer and van Wijk (2015) showed that such lithospheric mantle removal could also be responsible for the loss of lower crust at a passive rifted margin.

The volatile rich melting event of upper continental crustal material occurred during Stage $1(b)$ and is today recorded within the crystallized basaltic andesitic lava flows (Units A1 and A2 in the ODP Hole 642E core stratigraphy).

\subsubsection{Stage 2: the dacitic flows}

This stage started with Stage 2 (a) characterized by an explosive silicic volcanism in a subaerial environment. As a result, massive pyroclastic flows are deposited as ash-rich ignimbrite layers (S48 and S47).

The paleo-basin character of the Vøring Site 642 is defined by a massive deposition of ignimbrites. The ash cloud deposit on top of the ignimbrite is believed to be a Layer 3 of a classical ignimbrite flow unit. This sediment has settled from the ash cloud overriding the pyroclastic flow. On top of the ignimbrite, the sediments have a silt grain size and include volcanic and crustal material.

The Stage $2(a)$ is followed by the Stage $2(b)$ characterized by partial melting at shallower level (Fig. 9). It explains the dacitic flows of units B1 and B2. Samples of these units show hydrothermal alteration and devitrification supporting a subaqueous environment or interaction with wet/or shallow sediments. The geochemistry and the $\mathrm{Pb}$ isotopes ratio suggest an upper crustal rock-mantle magma interaction with a significant contribution of organic carbon rich pelagic sedimentary material during crustal anataxis. Combined stable carbon isotope and dinoflagellate cyst biostratigraphy analyses indicate an earliest Eocene age ( 56$55 \mathrm{Ma}$ ) for the Lower Series Flows, and postdating the PETM.

\subsubsection{Stage 3: the proto-breakup phase}

This stage is characterized by explosive volcanism. The ash fallout in a subaerial to subaqueous environment gave rise to the $13 \mathrm{~m}$ thick tuff layer S43 identified in the ODP Hole 642E core stratigraphy. The continuous uplift of the outer Vøring Margin due to the increased volcanic activity is responsible for the change of the depositional environment from shallow marine to subaerial. The sills D6s and D5s cross cutting the dacitic and the andesitic flows, respectively, were likely intruded during this stage.

\subsubsection{Stage 4: main breakup phase}

This stage is characterized not only by an increasing of the heat flow but also by a migration of the eruption centers toward the protobreakup axis. This stage started with a subaerial erosion of the tuff layer (Fig. 9). The main magma pulse during this stage is responsible for the emplacement of huge volumes of tholeiitic lava flows filling the paleorift topography. The continuous buildup of the extrusives gave rise to the different volcanic seismic facies unit identified in the 2D seismic reflection profiles. This phase coincides with the formation of SDR prism (the Upper Series in the ODP Hole 642E). Intense plumbing of the crust by dykes and sill intrusions in the near sedimentary basin characterizes this stage. The focused volcanism at the main injection center could possibly correspond to a decreasing volcanic activity in the landward Vøring Basin. Systematic reflector truncation on KReflector is due to both landward thinning and pinch-out of flows. Further east, the Utgard High sills showing the same isotope geochemistry than the Upper Series and by revealing an age of $~ 56-55$ Ma, give an indication of the age for the early breakup phase.

\section{Conclusions}

On the Vøring Margin, sub-basalt mapping results from new and reprocessed seismic reflection data combined with updated petrologi$\mathrm{cal} /$ geochemical reevaluation of the ODP Hole 642E. This provides more accurate constraints on the pre-breakup to initial breakup magmatic processes on the Vøring Margin.

Sub-basalt improved imaging allows the definition of a new seismic facies unit called the Lower Series Flows. This facies unit is characterized by wavy to continuous subparallel reflections with an internal disrupted and hummocky shape.

The Lower Series Flows record the transition from a sedimentary amagmatic rift toward the formation of the magmatic dominated rift in the Vøring Margin.

The Lower Series Flows show clear evidence of the hydrous anatexis of the pre-existing continental upper crust and magma contamination/ assimilation before fast SDR emplacement.

The isotope geochemistry points to MORB-like melts interacting with a highly radiogenic pelagic sedimentary body with significant organic carbon content within the melting crustal segment.

Results from palynological and stable carbon isotope studies indicate an early Eocene age for the Lower Series Flows; we show that sediments postdate the Paleocene-Eocene thermal maximum (PETM) $(\sim 56)$.

Our results show that the breakup process in the Vøring Margin happened during the early Eocene.

Our proposed evolutionary sequence for the Lower Series Flows facies unit includes (1) subaqueous basaltic andesitic flows intruding and extruding into wet sediments; (2) subaerial to shallow marine volcanism and extrusion of the dacitic flows; (3) the proto-breakup phase with intense shallow marine to explosive subaerial volcanism forming pyroclastic flows defining the K-Reflection; and (4) the main breakup stage with intense tholeiitic volcanism and large subsidence leading to the to the construction of the SDR wedge.

\section{Acknowledgments}

Founding for this work came from the OMNIS Project: Offshore MidNorwegian: Integrated Margin and Basin Studies (Project Number: 210429/E30) funded by the Norwegian Research Council through its Centre of Excellence CEED (Centre for Earth Evolution and Dynamics). The European Research Council (ERC) under the European Union Seventh Framework Program provided funding for this work by ERC Starting Grant 259627 to Sluijs. We thank Stella Heijnens and Arnold van Dijk for generating $\delta^{13} \mathrm{C}$ data and Natasja Welters for palynological sample preparation (all at Utrecht University). Seismic interpretation was done using HS: Kingdom software. Grid interpolations and map compilations were established using Geosoft Oasis Montaj and ArcGis software. We thank Jan. Hertogen, an anonymous reviewer, and the editor for useful comments that improved the paper.

\section{References}

Abdelmalak, M.M., 2010. Transition Spatio-temporelle entre rift sédimentaire et marge passive volcanique: l'exemple de la Baie de Baffin, Centre Ouest Groenland (Spatiotemporal transition between a sedimentary basin to a volcanic passive margin: the Baffin Bay case example, Central West Greenland). Université du Maine, France p. 266 (Available at onnline: http://cyberdoc.univ-lemans.fr/theses/2010/ 2010LEMA1030.pdf, Le Mans).

Abdelmalak, M.M., Geoffroy, L., Angelier, J., Bonin, B., Callot, J.P., Gélard, J.P., Aubourg, C., 2012. Stress fields acting during lithosphere breakup above a melting mantle: a case example in West Greenland. Tectonophysics 581, 132-143. 
Abdelmalak, M.M., Andersen, T.B., Planke, S., Faleide, J.I., Corfu, F., Tegner, C., Shephard, G.E., Zastrozhnov, D., Myklebust, R., 2015. The ocean-continent transition in the mid-Norwegian margin: insight from seismic data and an onshore Caledonian field analogue. Geology 43, 1011-1014.

Abdelmalak, M.M., Planke, S., Faleide, J.I., Jerram, D.A., Zastrozhnov, D., Eide, S., Myklebust, R., 2016. Development of escarpments at volcanic rifted margins: insights from the Vøring Escarpment, mid-Norwegian Margin (submitted for publication).

Berndt, C., Skogly, O.P., Planke, S., Eldholm, O., Mjelde, R., 2000. High-velocity breakuprelated sills in the Vøring Basin, off Norway. J. Geophys. Res. 105, 28,443-428,454.

Berndt, C., Planke, S., Alvestad, E., Tsikalas, F., Rasmussen, T., 2001. Seismic volcanostratigraphy of the Norwegian Margin: constraints on tectonomagmatic break-up processes. J. Geol. Soc. 158, 413-426.

Blystad, P., Brekke, H., Færseth, R.B., Larsen, B.T., Skogseid, J., Tørudbakken, B., 1995. Structural elements of the Norwegian continental shelf. Part II: the Norwegian Sea Region. NPD-Bulletin, The Norwegian Petroleum Directorate, p. 8.

Boulter, M.C., Manum, S.B., 1989. The Brito-Arctic igneous province flora around the Paleocene/Eocene boundary. In: Eldholm, O., Thiede, J., Taylor, E. (Eds.), Proceedings of the Ocean Drilling Program, Scientific Results, pp. 663-680.

Breivik, A., Faleide, J.I., Mjelde, R., Flueh, E., Murai, Y., 2014. Magmatic development of the outer Vøring Margin from seismic data. J. Geophys. Res. Solid Earth 119 6733-6755.

Brekke, H., 2000. The tectonic evolution of the Norwegian Sea Continental Margin with emphasis on the Vøring and Møre basins. Geol. Soc. Lond., Spec. Publ. 167, 327-378.

Brekke, H., Sjulstad, H.I., Magnus, C., Williams, R.W., 2001. Sedimentary environments offshore Norway- an overview. In: Ole, J.M., Tom, D. (Eds.), Norwegian Petroleum Society Special Publications. Elsevier, pp. 7-37.

Brendt, C., Planke, S., Alvestad, E., Tsikalas, F., Rasmussen, T., 2001. Seismic volcanostratigraphy of the Norwegian margin: constraints on tectonomagmatic break-up processes. J. Geol. Soc. Lond. 158, 413-426.

Bryan, S.E., Riley, T.R., Jerram, D.A., Stephens, C.J., Leat, P.T., 2002. Silicic volcanism: an undervalued component of large igneous provinces and volcanic rifted margins. In: Menzies, M.A., Klemperer, S.L., Ebinger, C.J., Baker, J. (Eds.), Volcanic Rifted Margins. Geological Society of America, Boulder, Colorado, pp. 97-118.

Callot, J.P., Grigné, C., Geoffroy, L., Brun, J.-P., 2001. Development of volcanic passive margin: 2D laboratory models. Tectonics 20, 148-159.

Callot, J.P., Geoffroy, L., Brun, J.-P., 2002. Development of volcanic passive margins: threedimensional laboratory models. Tectonics 335, 313-329.

Chappell, B.W., White, A.J.R., 1992. I- and S-type granites in the Lachlan Fold Belt. Earth Environ. Sci. Trans. R. Soc. Edinb. 83, 1-26.

Charles, A.J., Condon, D.J., Harding, I.C., Pälike, H., Marshall, J.E.A., Cui, Y., Kump, L., Croudace, I.W., 2011. Constraints on the numerical age of the Paleocene-Eocene boundary. Geochem. Geophys. Geosyst. 12, O0AA17.

Coffin, M.F., Eldholm, O., 1994. Large igneous provinces: crustal structure, dimensions and external consequence. Rev. Geophys. 32, 1-36.

Costa, L.I., Downie, C., 1976. The Distribution of the Dinoflagellate Wetzeliella in the Palaeogene of north-western Europe. Palaeontology 19, 591-614.

Doré, A.G., Lundin, E.R., Jensen, L.N., Birklamd, Ø., Eliassen, P.E., Fichler, C., 1999. Principal tectonic events in the evolution of the northwest European Atlantic margin. Geol. Soc Lond. Pet. Geol. Conf. Ser. 5, 41-61.

Eldholm, O., 1991. Magmatic-tectonic evolution of a volcanic rifted margin. Mar. Geol. $102,43-61$.

Eldholm, O., Grue, K., 1994. North Atlantic volcanic margins: dimensions and production rates. J. Geophys. Res. 99, 2955-2968.

Eldholm, O., Thiede, J., Taylor, E., Party, S.S., 1987. Summary and preliminary conclusions, ODP Leg 104. In: Eldholm, O., Thiede, J., Taylor, E., et al. (Eds.), Proceedings of the Ocean Drilling Program, Scientific Results, pp. 751-771.

Eldholm, O., Thiede, J., Taylor, E., 1989a. Evolution of the Vøring Volcanic Margin. In: Eldholm, O., Thiede, J., Taylor, E. (Eds.), Proceedings of the Ocean Drilling Program, Scientific Results, pp. 1033-1065.

Eldholm, O., Thiede, J., Taylor, E., Eldholm, O., 1989b. The Norwegian continental margin: tectonic, volcanic, and paleoenvironmental framework. In: Thiede, J., Taylor, E. (Eds.), Proceedings of the Ocean Drilling Program, Scientific Results, pp. 5-26.

Eldholm, O., Gladczenko, T.P., Skogseid, J., Planke, S., 2000. Atlantic volcanic margins: a comparative study. In: NOTTVEDT, A.e.a. (Ed.), Dynamics of the Norwegian MarginSpetial Publications, London. Geological Society, London, pp. 411-428.

Eldholm, O., Tsikalas, F., Faleide, J.I., 2002. Continental margin off Norway $62-75^{\circ} \mathrm{N}$ : palaeogene tectono-magmatic segmentation and sedimentation. Geol. Soc. Lond., Spec. Publ. 197, 39-68.

Ellam, R.M., Stuart, F.M., 2000. The sub-lithospheric source of North Atlantic basalts: evidence for, and significance of, a common end-member. J. Petrol. 41 919-932.

Esedo, R., van Wijk, J., Coblentz, D., Meyer, R., 2012. Uplift prior to continental breakup: indication for removal of mantle lithosphere? Geosphere 8, 1078-1085.

Faleide, J.I., Tsikalas, F., Breivik, A.J., Mjelde, R., Ritzmann, O., Engen, Ø., Wilson, J., Eldholm, O., 2008. Structure and evolution of the continental margin off Norway and the Barents Sea. Episodes 31, 82-91.

Faleide, J., Bjørlykke, K., Gabrielsen, R., 2010. Geology of the Norwegian Continental Shelf, Petroleum Geoscience. Springer, Berlin Heidelberg, pp. 467-499.

Fitton, J.G., Saunders, A.D., Larsen, L.M., Hardarson, B.S., Norry, M.J., 1998. Volcanic rocks from the Southeast Greenland margin at $63^{\circ} \mathrm{N}$ : composition, petrogenesis, and mantle source. In: Saunders, A.D., Larsen, H.C., Wise, S.W.J. (Eds.), Proceeding of the Ocean Drilling Program: Scientific Results. Ocean Drilling Program, College Station TX pp. 331-350.
Ganerød, M., Smethurst, M.A., Torsvik, T.H., Prestvik, T., Rousse, S., McKenna, C., Van Hinsbergen, D.J.J., Hendriks, B.W.H., 2010. The North Atlantic Igneous Province reconstructed and its relation to the plume generation zone: the Antrim Lava Group revisited. Geophys. J. Int. 182, 183-202.

Geldmacher, J., Troll, V.R., Emeleus, C.H., Donaldson, C.H., 2002. Pb-isotope evidence for contrasting crustal contamination of primitive to evolved magmas from Ardnamurchan and Rum: implications for the structure of the underlying crust. Scott. J. Geol. 38, 55-61.

Geoffroy, L., 2005. Volcanic passive margins. C. R. Géosci. 337, 1395-1408.

Geoffroy, L., Aubourg, C., Callot, J.P., Barrat, J.A., 2007. Mechanisms of crustal growth in large igneous provinces: the North Atlantic province as case study. Geol. Soc. Am. Spec. Pap. 430, 747-774.

Gernigon, L., Ringenbach, J.-C., Planke, S., Jonquet-Kolsto, H., 2003. Extension, crustal structure and magmatism at the outer Voring Basin, Norwegian margin. J. Geol. Soc. Lond. 160, 197-208.

Gernigon, L., Ringenbach, J.-C., Planke, S., Le Gall, B., 2004. Deep structures and breakup along volcanic rifted margins: insights from integrated studies along the outer Vøring Basin (Norway). Mar. Pet. Geol. 21, 363-372.

Gernigon, L., Olesen, O., Ebbing, J., Wienecke, S., Gaina, C., Mogaard, J.O., Sand, M., Myklebust, R., 2009. Geophysical insights and early spreading history in the vicinity of the Jan Mayen Fracture Zone, Norwegian-Greenland Sea. Tectonophysics 468, 185-205.

Gernigon, L., Blischke, A. Nasuti, A., Sand, M., 2015. Conjugate volcanic rifted margins, sea-floor spreading and microcontinent: insights from new high-resolution aeromagnetic surveys in the Norway Basin. Tectonics (2014TC003717).

Goll, R.M., 1989. A synthesis of Norwegian Sea biostratigraphies: ODP Leg 104 on the Vøring Plateau. In: Eldholm, O., Thiede, J., Taylor, E. (Eds.), Proceedings of the Ocean Drilling Program, Scientific Results, pp. 777-826

Gradstein, F.M., Ogg, J.G., Schmitz, M.D., Ogg, G.M., 2012. The Geologic Time Scale 2012.

Hamelin, B., Grousset, F., Sholkovitz, E.R., 1990. Pb isotopes in surficial pelagic sediments from the North Atlantic. Geochim. Cosmochim. Acta 54, 37-47.

Hansen, J., Jerram, D.A., McCaffrey, K., Passey, S.R., 2009. The onset of the North Atlantic igneous province in a rifting perspective. Geol. Mag. 146, 309-325.

Harland, R., 1979. The Wetzeliella (Apectodinium) homomorpha plexus from the Palaeocene/earliest Eocene of north-west Europe. Proc. Int. Palynol. Conf. 4th. 1976-77, 59-70 Lucknow

Hayes, J.M., Strauss, H., Kaufman, A.J., 1999. The abundance of 13C in marine organic matter and isotopic fractionation in the global biogeochemical cycle of carbon during the past 800 Ma. Chem. Geol. 161, 103-125.

Hinz, K., 1981. Hypothesis on terrestrial catastrophes: wedges of very thick oceanward dipping layers beneath passive margins-their origin and palaeoenvironement significance. Geol. Jahrb. 22, 345-363.

Hinz, K., Dostmann, H.J., Hanisch, J., 1982. Structural framework of the Norwegian Sea, offshore Northern Seas. Nor. Pet. Soc. 1-22.

Hinz, K., Dostman, H.J., Hanisch, J., 1984. Structural elements of the Norwegian Sea continental margin. Geol. Jahrb. 75, 193-211.

Holbrook, W.S., Larsen, H.C., Korenaga, J., Dahl-Jensen, T., Reid, I.D., Kelemen, P.B., Hopper, J.R., Kent, G.M., Lizarralde, D., Bernstein, S., Detrick, R.S., 2001. Mantle thermal structure and active upwelling during continental breakup in the North Atlantic. Earth Planet. Sci. Lett. 190, 251-266.

Jerram, D.A., Single, R.T., Hobbs, R.W., Nelson, C.E., 2009. Understanding the offshore flood basalt sequence using onshore volcanic facies analogues: an example from the FaroeShetland basin. Geol. Mag. 146, 353-367.

Karson, J.A., Brooks, C.K., 1999. Structural and magmatic segmentation of the Tertiary east Greenland volcanic rifted margin. In: Ryan, P., McNiocaill, C. (Eds.), J.F. Dewey Volume On Continental Tectonics. Geological Society Special Publication, pp. 313-318.

Kelemen, P.B., Holbrook, W.S., 1995. Origin of thick, high-velocity igneous crust along the U.S. East Coast Margin. J. Geophys. Res. 100, 10077-10094.

Klausen, M.B., Larsen, H.C., 2002. East Greenland coast-parallel dike swarm and its role in continental breakup. In: Menzie, M.A., Klemperer, S.L., Ebinger, C.J., Baker, J. (Eds.), Volcanic Rited Margins: Boulder, Colorado. Geological Society of America Special Paper 362, pp. 133-158.

Le Bas, M.J., Le Maitre, R.W., Streckeisen, A., Zanettini, B., Rocks, I.S.o.t.S.o.I., 1986. A chemical classification of volcanic rocks based on the total alkali-silica diagram. J. Petrol. 27, 745-750.

LeHuray, A.P., Johnson, E.S., 1989. Rb-Sr systematics of site 642 volcanic rocks and alteration minerals. In: Eldholm, O., Thiede, J., Taylor, E. (Eds.), Proceedings of the Ocean Drilling Program, Scientific Results, pp. 437-448.

Lenoir, X., Féraud, G., Geoffroy, L., 2003. High-rate flexure of the East Greenland rifted margin: constrain from ${ }^{40} \mathrm{Ar} /{ }^{39} \mathrm{Ar}$ dating of basaltic dykes. Earth Planet. Sci. Lett. 214, 515-528.

Li, Y.-H., 1991. Distribution patterns of the elements in the ocean: a synthesis. Geochim. Cosmochim. Acta 55, 3223-3240.

Love, D.A., Frape, S.K., Gibson, I.L., Jones, M.G., 1989. The $\delta^{18} \mathrm{O}$ and $\delta^{13} \mathrm{C}$ isotopic composition of secondary carbonates from basaltic lavas cored in Hole 642E, Ocean Drilling Program Leg 104. In: Eldholm, O., Thiede, J., Taylor, E. (Eds.), Proceedings of the Ocean Drilling Program, Scientific Results, pp. 449-455.

Lundin, E.R., Doré, A.G., 2005. NE Atlantic break-up: a re-examination of the Iceland mantle plume model and the Atlantic-Arctic linkage. Geol. Soc. Lond. Pet. Geol. Conf. Ser. 6, 739-754

Maniar, P.D., Piccoli, P.M., 1989. Tectonic discrimination of granitoids. Geol. Soc. Am. Bull. 101, 635-643.

Maus, S., Barckhausen, U., Berkenbosch, H., Bournas, N., Brozena, J., Childers, V., Dostaler, F., Fairhead, J.D., Finn, C., von Frese, R.R.B., Gaina, C., Golynsky, S., Kucks, R., Lühr, H., Milligan, P., Mogren, S., Müller, R.D., Olesen, O., Pilkington, M., Saltus, R., Schreckenberger, B., Thébault, E., Caratori Tontini, F., 2009. EMAG2: a 2-arc min 
resolution earth magnetic anomaly grid compiled from satellite, airborne, and marine magnetic measurements. Geochem. Geophys. Geosyst. 10, Q08005.

McDonough, W.F., Sun, S.S., 1995. The composition of the Earth. Chem. Geol. 120, 223-253.

McInerney, F.A., Wing, S.L., 2011. The Paleocene-Eocene thermal maximum: a perturbation of Carbon cycle, climate, and biosphere with implications for the future. Annu. Rev. Earth Planet. Sci. 39, 489-516.

Menzie, M.A., Klemperer, S.L., Ebinger, C.J., Baker, J., 2002. Characteristics of volcanic rifted margins. Geol. Soc. Am. 1-14.

Meyer, R., van Wijk, J., 2015. Post-breakup lithosphere recycling below the U.S. East Coast: evidence from adakitic rocks. Geol. Soc. Am. Spec. Pap. 514, 65-85.

Meyer, R., van Wijk, J., Gernigon, L., 2007. The North Atlantic igneous province: a review of models for its formation. Geol. Soc. Am. Spec. Pap. 430, 525-552.

Meyer, R., Hertogen, J., Pedersen, R.B., Viereck-Götte, L., Abratis, M., 2009a. Interaction of mantle derived melts with crust during the emplacement of the Vøring Plateau, N.E. Atlantic. Mar. Geol. 261, 3-16.

Meyer, R., Nicoll, G., Hertogen, J., Troll, V., Ellam, R., Emeleus, C., 2009b. Trace element and isotope constraints on crustal anatexis by upwelling mantle melts in the North Atlantic Igneous Province: an example from the Isle of Rum, NW Scotland. Mag. 146, 382-399.

Meyer, R., Haaga, K.A., Pedersen, R.B., 2016. Geological and petrogenetic constraints on the Jan Mayen Ridge formation and crustal basement (submitted for publication).

Mjelde, R., Raum, T., Murai, Y., Takanami, T., 2007. Continent-ocean-transitions: review, and a new tectono-magmatic model of the Vøring Plateau, NE Atlantic. J. Geodyn. 43, 374-392.

Mjelde, R., Faleide, J.I., Breivik, A.J., Raum, T., 2009a. Lower crustal composition and crustal lineaments on the Vøring Margin, NE Atlantic: a review. Tectonophysics 472, 183-193.

Mjelde, R., Raum, T., Kandilarov, A., Murai, Y., Takanami, T., 2009b. Crustal structure and evolution of the outer Møre margin, NE Atlantic. Tectonophysics 468, 224-243.

Murphy, B.H., Farley, K.A., Zachos, J.C., 2010. An extraterrestrial 3He-based timescale for the Paleocene-Eocene thermal maximum (PETM) from Walvis Ridge, IODP Site 1266. Geochim. Cosmochim. Acta 74, 5098-5108.

Mutter, J.C., Talwani, M., Stoffa, P.L., 1982. Origin of seaward-dipping reflectors in oceanic crust off the Norwegian margin by “subaerial sea-floor spreading”. Geology 10, 353-357.

Nelson, C.E., Jerram, D.A., Single, R.T., Hobbs, R.W., 2009. Understanding the facies architecture of flood basalts and volcanic rifted margins and its effect on geophysical properties. In: Varming, T., Ziska, H. (Eds.), Faroe Islands Exploration Conference: Proceedings of the 2nd Conference, Annales Societatis Scientarium Faroensis, supplementum, pp. 83-103.

Neumann, E.-R., Svensen, H., Tegner, C., Planke, S., Thirlwall, M., Jarvis, K.E., 2013. Sill and lava geochemistry of the mid-Norway and NE Greenland conjugate margins. Geochem. Geophys. Geosyst. 14, 3666-3690.

Olesen, O., Ebbing, J., Lundin, E., Mauring, E., Skilbrei, J.R., Torsvik, T.H., Hansen, E.K. Henningsen, T., Midbøe, P., Sand, M., 2007. An improved tectonic model for the Eocene opening of the Norwegian-Greenland Sea: use of modern magnetic data. Mar. Pet. Geol. 24, 53-66.

Parson, L., Viereck, L., Love, D., Gibson, I., Morton, A., Hertogen, J., 1989. The petrology of the lower series volcanics, ODP Site 642. In: Eldholm, O., Thiede, J., Taylor, E., et al. (Eds.), Proceedings of the Ocean Drilling Program, Scientific Results, pp. 419-428.

Planke, S., 1994. Geophysical response of flood basalts from analysis of wire line logs: Ocean Drilling Program Site 642, Vøring volcanic margin. J. Geophys. Res. 99, 9279-9296.

Planke, S., Alvestad, E., 1999. Seismic volcanostratigraphy of the extrusive breakup complexes in the northeast Atlantic: implications from ODP/DSDP drilling. In: Larsen, H.C., Duncan, R.A., Allan, J.F., Brooks, K. (Eds.), Proceedings of the Ocean Drilling Program, Scientific Results, pp. 3-16.

Planke, S., Eldholm, O., 1994. Seismic response and construction of seaward dipping wedges of flood basalts: Vøring volcanic margin. J. Geophys. Res. 99, 9263-9278.

Planke, S., Alvestad, E., Eldholm, O., 1999. Seismic characteristics of basaltic extrusive and intrusive rocks. Lead. Edge 342-348.

Planke, S., Symonds, P.A., Avelstad, E., Skogseid, J., 2000. Seismic volcanostratigraphy of large-volume basaltic extrusive complexes on rifted margins. J. Geophys. Res. 105, 19333-19351.

Planke, S., Rasmussen, T., Rey, T., Myklebust, R., 2005. Seismic characteristics and distribution of volcanic intrusions and hydrothermal vent complexes in the Vøring and Møre basins. In: Doré, A.G., Vining, B.A. (Eds.), Petroleum Geology: North-West Europe and Global Perspectives-Proceedings of the 6th Petroleum Geology Conference. Geological Society, London, pp. 833-844.

Planke, S., Svensen, H., Myklebust, R., Bannister, S., Manton, B., Lorenz, L., 2015. Geophysics and Remote Sensing. Springer, Berlin Heidelberg, pp. 1-16.

Ren, S., Faleide, J.I., Eldholm, O., Skogseid, J., Gradstein, F., 2003. Late CretaceousPaleocene tectonic development of the NW Vøring basin. Mar. Pet. Geol. 20, 177-206.

Rey, S.S., Planke, S., Symonds, P.A., Faleide, J.I., 2008. Seismic volcanostratigraphy of the Gascoyne Margin, Western Australia. J. Volcanol. Geotherm. Res. 172, 112-131.

Röhl, U., Westerhold, T., Bralower, T.J., Zachos, J.C., 2007. On the duration of the PaleoceneEocene thermal maximum (PETM). Geochem. Geophys. Geosyst. 8, Q12002.

Sandwell, D.T., Smith, W.H.F., 2009. Global marine gravity from retracked Geosat and ERS1 altimetry: ridge segmentation versus spreading rate. J. Geophys. Res. Solid Earth 114, B01411.

Saunders, A.D., Fitton, J.G., Kerr, A.C., Norry, M.J., Kent, R.W., 1997. The North Atlantic igneous province. In: Mahoney, J.J., Coffin, M.F. (Eds.), Large Igneous Provinces:
Continental, Oceanic, and Planetary Flood Volcanism. AGU Geophysical Monograph, Washington, pp. 45-93.

Scheck-Wenderoth, M., Raum, T., Faleide, J.I., Mjelde, R., Horsfield, B., 2007. The transition from the continent to the ocean: a deeper view on the Norwegian margin. J. Geol. Soc. $164,855-868$.

Schmitz, B., Peucker-Ehrenbrink, B., Heilmann-Clausen, C., Åberg, G., Asaro, F., Lee, C.-T.A., 2004. Basaltic explosive volcanism, but no comet impact, at the Paleocene-Eocene boundary: high-resolution chemical and isotopic records from Egypt, Spain and Denmark. Earth Planet. Sci. Lett. 225, 1-17.

Schönharting, G., Abrahamsen, N., 1989. Paleomagnetism of the volcanic sequence in hole 642e, ODP Leg 104, Vøring Plateau, and correlation with early Tertiary basalts in the North Atlantic. In: Eldholm, O., Thiede, J., Taylor, E., et al. (Eds.), Proceedings of the Ocean Drilling Program, Scientific Results, pp. 911-920.

Sinton, C.W., Duncan, R.A., 1998. ${ }^{40} \mathrm{Ar}-{ }^{39} \mathrm{Ar}$ ages of the lavas from the southeast Greenland margin, ODP leg 152, and the Rockall plateau, DSDP leg 81. In: Saunders, A.D., Larsen, H.C., Wise, S.W.J. (Eds.), Proceeedings of the Ocean Drilling Program, Scientific Results. Ocean Drilling Program, College Station TX, pp. 387-402.

Sinton, C.W., Hitchen, K., Duncan, R.A., 1998. 40 Ar-39 Ar geochronology of silicic and basic volcanic rocks on the margins of the North Atlantic. Geol. Mag. 135, 161-170.

Skogseid, J., Eldholm, O., 1987. Early Cenozoic crust at the Norwegian continental margin and the conjugate Jan Mayen Ridge. J. Geophys. Res. Solid Earth 92, 11471-11491.

Skogseid, J., Planke, S., Faleide, J.I., Pedersen, T., Eldholm, O., Neverdal, F., 2000. NE Atlantic continental rifting and volcanic margin formation. In: NOTTVEDT, A.e.a. (Ed.), Dynamics of the Norwegian MarginSpecial Publications, London. Geological Society, London, pp. 295-326.

Sluijs, A., Dickens, G.R., 2012. Assessing offsets between the $\delta 13 C$ of sedimentary components and the global exogenic carbon pool across early Paleogene carbon cycle perturbations. Glob. Biogeochem. Cycles 26 (n/a-n/a).

Sluijs, A., Schouten, S., Pagani, M., Woltering, M., Brinkhuis, H., Damsté, J.S.S., Dickens, G.R. Huber, M., Reichart, G.-J., Stein, R., Matthiessen, J., Lourens, L.J., Pedentchouk, N., Backman, J., Moran, K., the Expedition, S., 2006. Subtropical Arctic Ocean temperatures during the Palaeocene/Eocene thermal maximum. Nature 441, 610-613.

Sluijs, A., Bijl, P.K., Schouten, S., Röhl, U., Reichart, G.J., Brinkhuis, H., 2011. Southern ocean warming, sea level and hydrological change during the Paleocene-Eocene thermal maximum. Clim. Past 7, 47-61.

Sluijs, A., Zachos, J.C., Zeebe, R.E., 2012. Constraints on hyperthermals. Nat. Geosci. 5, 231.

Svensen, H., Planke, S., Malthe-Sorenssen, A., Jamtveit, B., Myklebust, R., Rasmussen Eidem, T., Rey, S.S., 2004. Release of methane from a volcanic basin as a mechanism for initial Eocene global warming. Nature 429, 542-545.

Svensen, H., Planke, S., Corfu, F., 2010. Zircon dating ties NE Atlantic sill emplacement to initial Eocene global warming. J. Geol. Soc. 167, 433-436.

Taylor, P.N., Morton, A.C., 1989. Sr, Nd, and Pb isotope geochemistry of ODP Hole 104642E, Supplement to: Taylor, Paul N; Morton, Andrew C (1989): Sr, Nd, and Pb isotope geochemistry of the upper and lower volcanic series at Site 642. In: Eldholm, O., Thiede, J., Taylor, E., et al. (Eds.), Proceedings of the Ocean Drilling Program, Scientific Results 104. Ocean Drilling Program, College Station, TX, pp. 429-435. http://dx. doi.org/10.2973/odp.proc.sr.104.133.1989 (PANGAEA).

Torsvik, T.H., Mosar, J., Eide, E.A., 2001. Creataceous-Tertiary geodynamics: a North Atlantic exercise. Geophys. J. Int. 146, 850-866.

Tsikalas, F., Faleide, J.I., Kuznir, N.J., 2008. Along-strike variations in rifted margin crustal architecture and lithosphere thinning between northern Vøring and Lofoten margin segments off mid-Norway. Tectonophysics 458, 68-81.

Tsikalas, F., Faleide, J.I., Eldholm, O., Antonio Blaich, O., 2012. 5 - The NE Atlantic Conjugate Margins. In: Bally, D.G.R.W. (Ed.), Regional Geology and Tectonics: Phanerozoic Passive Margins, Cratonic Basins and Global Tectonic Maps. Elsevier, Boston, pp. 140-201.

Vandenberghe, N., Hilgen, F.J., Speijer, R.P., Ogg, J.G., Gradstein, F.M., Hammer, O., Hollis, C.J., Hooker, J.J., 2012. Chapter 28 - The Paleogene Period. The Geologic Time Scale. Elsevier, Boston, pp. 855-921.

Viereck, L.G., Hertogen, J., Parson, L.M., Morton, A.C., Love, D., Gibson, I.L., 1989 Chemical stratigraphy and petrology of the Vøring Plateau: theoleiitic lavas and interlayered volcaniclastic sediments at ODP Hole 642E. In: Eldholm, O., Thiede, J., Taylor, E., et al. (Eds.), Proceedings of the Ocean Drilling Program, Scientific Results, pp. 367-396.

Westerhold, T., Röhl, U., Laskar, J., 2012. Time scale controversy: accurate orbital calibration of the early Paleogene. Geochem. Geophys. Geosyst. 13, Q06015.

White, R.S., McKenzie, D.P., 1989. Magmatism at rift zones: the generation of volcanic continental margins and flood basalts. J. Geophys. Res. 94, 7685-7729.

White, R.S., Spence, G.D., Fowler, S.R., McKenzie, D.P., Westbrook, G.K., Bowen, A.N., 1987. Magmatism at rifted continental margins. Nature 330, 439-444.

Williams, G.L., Brinkhuis, H., Pearce, M.A., Fensome, R.A., Weegink, J.W., 2004. Southern Ocean and global dinoflagellate cyst events compared: index events for the Late Cretaceous-Neogene. In: Exon, N.F., Kennett, J.P., Malone, M.J. (Eds.), Proceedings Ocean Drilling Program. Scientific Results, College Station, Texas, pp. 1-98.

Wright, K.A., Davies, R.J., Jerram, D.A., Morris, J., Fletcher, R., 2012. Application of seismic and sequence stratigraphic concepts to a lava-fed delta system in the Faroe-Shetland Basin, UK and Faroes. Basin Res. 24, 91-106.

Yamasaki, T., Gernigon, L., 2009. Styles of lithospheric extension controlled by underplated mafic bodies. Tectonophysics 468, 169-184.

Ziegler, P.A., 1988. Evolution of the Arctic-North Atlantic and the Western Tethys. AAPG Mem. 43. 